\title{
Two-Dimensional Flood-Inundation Model of the Flint River at Albany, Georgia
}

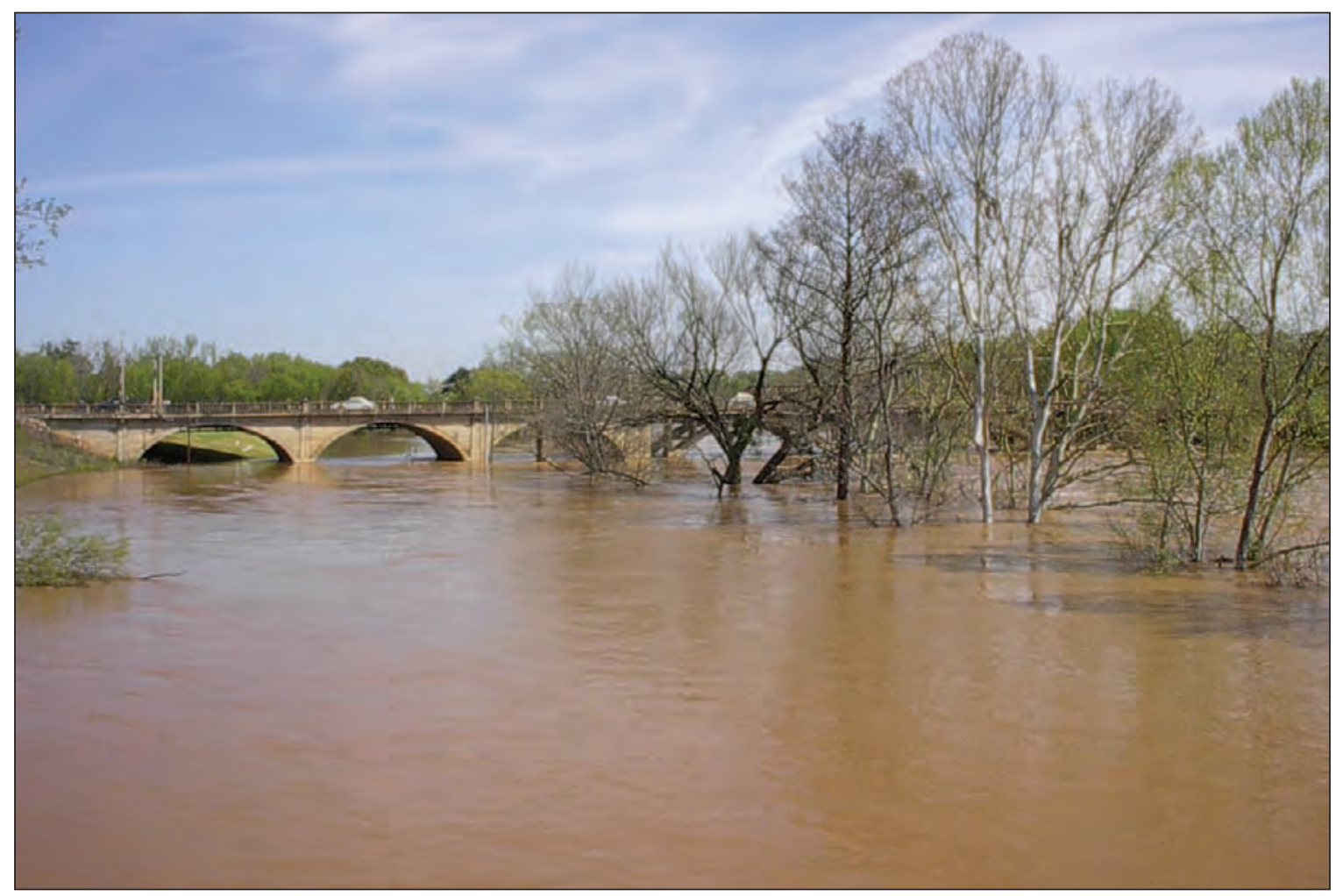

Scientific Investigations Report 2007-5107

In cooperation with Albany, Georgia, and Dougherty County, Georgia

U.S. Department of the Interior

U.S. Geological Survey 
Cover photograph: Broad Avenue bridge over the Flint River at Albany, Georgia, March 2005 Photograph by Jonathan W. Musser, U.S. Geological Survey 


\section{Two-Dimensional Flood-Inundation Model of the Flint River at Albany, Georgia}

By Jonathan W. Musser and Thomas R. Dyar

In cooperation with Albany, Georgia, and Dougherty County, Georgia

Scientific Investigations Report 2007-5107 


\title{
U.S. Department of the Interior DIRK KEMPTHORNE, Secretary
}

\author{
U.S. Geological Survey \\ Mark D. Myers, Director
}

\section{U.S. Geological Survey, Reston, Virginia: 2007}

For product and ordering information:

World Wide Web: http://www.usgs.gov/pubprod

Telephone: 1-888-ASK-USGS

For more information on the USGS — the Federal source for science about the Earth, its natural and living resources, natural hazards, and the environment:

World Wide Web: http://www.usgs.gov

Telephone: 1-888-ASK-USGS

Any use of trade, product, or firm names is for descriptive purposes only and does not imply endorsement by the U.S. Government.

Although this report is in the public domain, permission must be secured from the individual copyright owners to reproduce any copyrighted materials contained within this report.

Suggested citation:

Musser, Jonathan W., and Dyar, Thomas R., 2007, Two-dimensional flood-inundation model of the Flint River at Albany, Georgia: Atlanta, Georgia, U.S. Geological Survey Scientific Investigations Report 2007-5107, 49 p., Web-only publication at http://pubs.usgs.gov/sir/2007/5107 


\section{Contents}

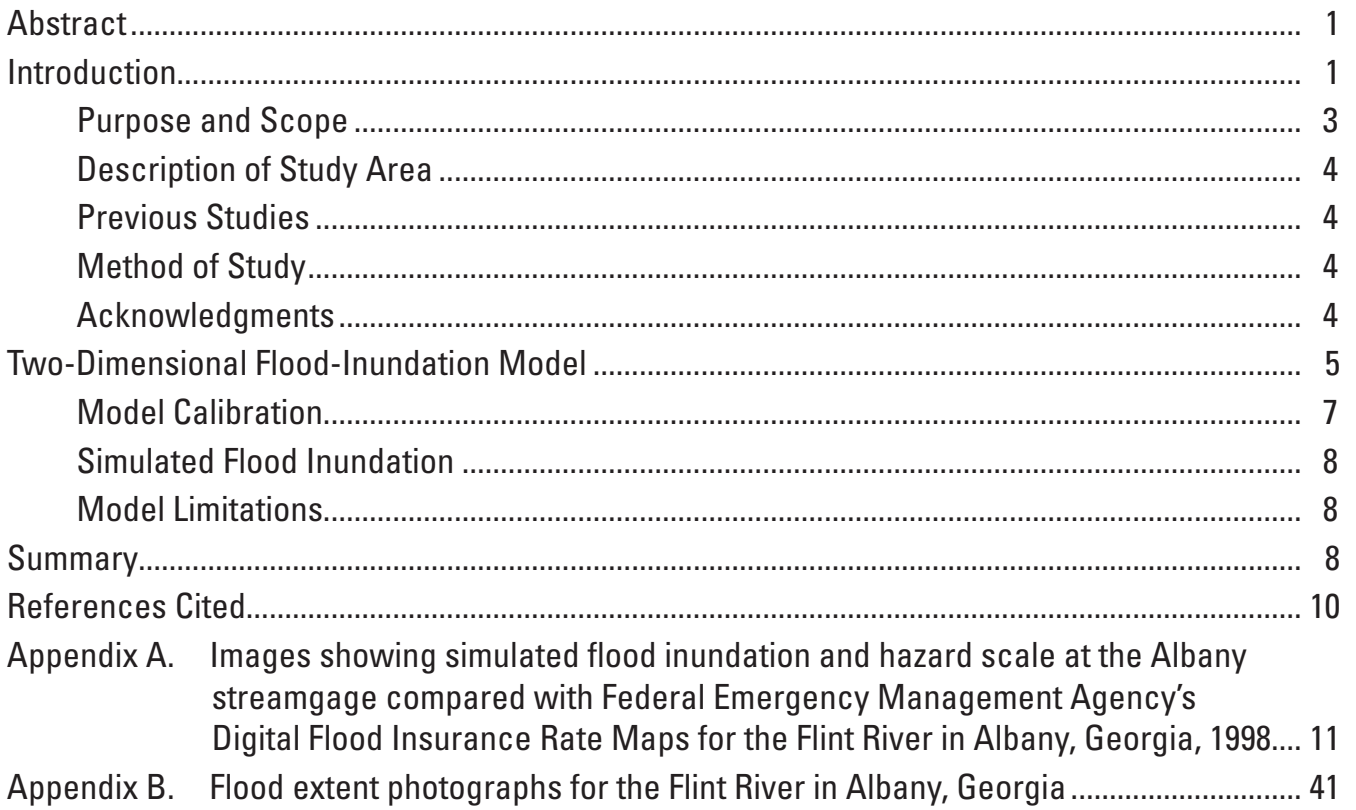

\section{Figures}

1. Map showing location of two-dimensional model study area along the study reach of the Flint River at Albany, Georgia

2. Image of flood-inundation study area showing all major Flint River crossings, Albany, Georgia

3-5. Maps Showing-

3. U.S. Geological Survey streamgages in the Flint River Basin, Georgia

4. Finite-element mesh used for two-dimensional model of the Flint River at Albany, Georgia. Inflow and outflow boundary conditions are for a water-surface altitude of 192.5 feet at the Albany streamgage.....

5. Velocity distribution of the Flint River near Oakridge Drive at Albany, Georgia ....9

6. Graph showing simulated flow profiles by streamgage altitude for the Flint River at Albany, Georgia 


\section{Figures-continued}

A1-A14. Images showing simulated flood inundation for a water-surface altitude at the Albany streamgage compared with Federal Emergency Management Agency's Digital Flood Insurance Rate Maps for the Flint River in Albany, Georgia, 1998-

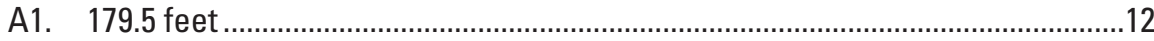

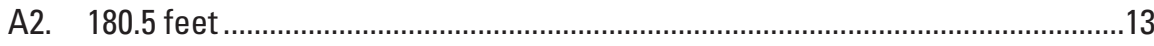

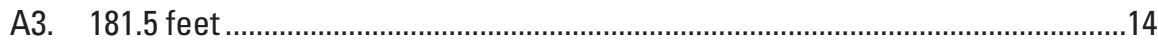

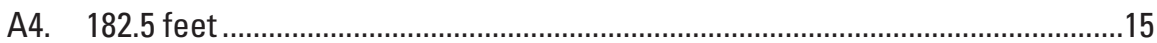

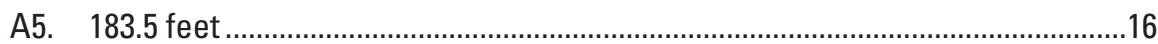

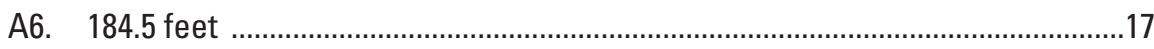

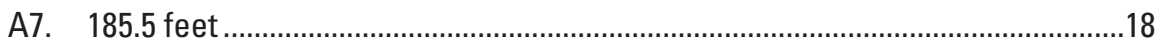

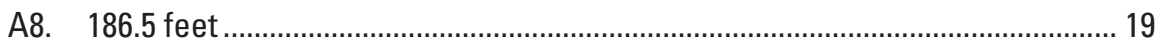

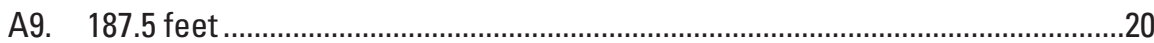

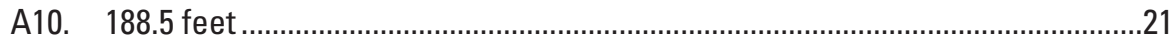

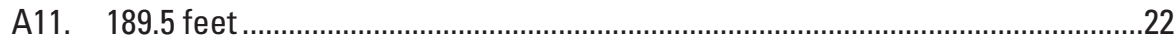

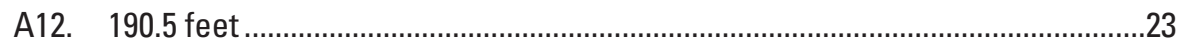

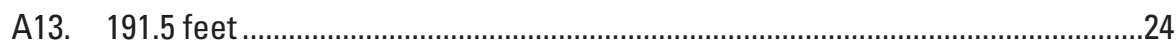

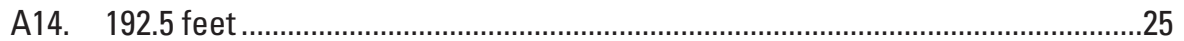

A15-A28. Images showing simulated flood-inundation hazard scale for a water-surface altitude at the Albany streamgage compared with Federal Emergency Management Agency's Digital Flood Insurance Rate Maps for the Flint River in Albany, Georgia, 1998-

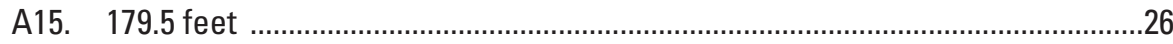

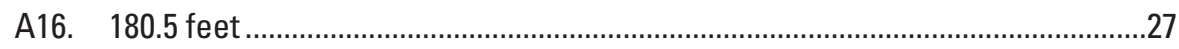

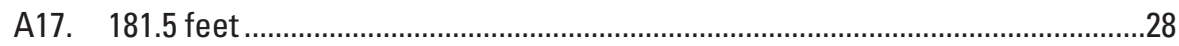

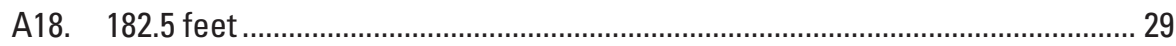

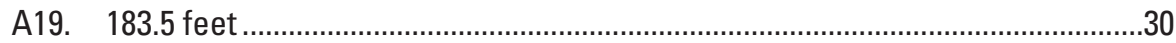

A20. 184.5 feet

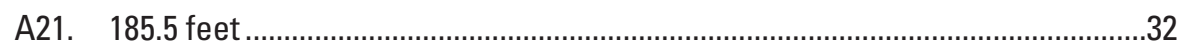

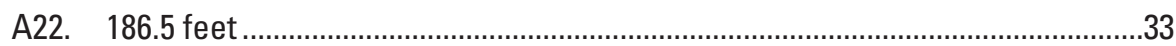

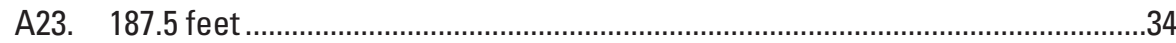

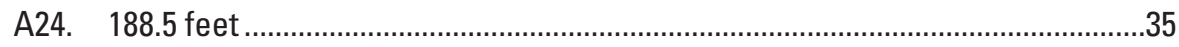

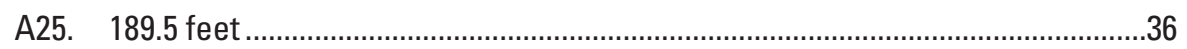

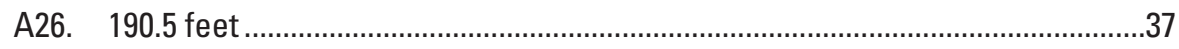

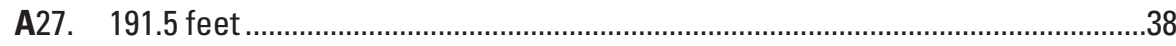

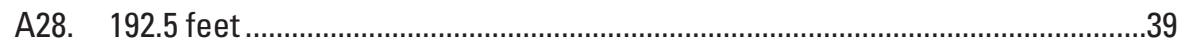

B1. Simulated flood inundation for a water-surface altitude of 181.5 feet at the Albany streamgage with locations of flood extent photographs for the Flint River in Albany, Georgia

B2. Flood extent photographs for the Flint River in Albany, Georgia .................................43 


\section{Conversion Factors and Datum}

\begin{tabular}{lcl}
\hline \multicolumn{1}{c}{ Multiply } & By & \multicolumn{1}{c}{ To obtain } \\
\hline & Length & \\
\hline inch (in.) & 2.54 & centimeter $(\mathrm{cm})$ \\
inch (in.) & 25.4 & millimeter $(\mathrm{mm})$ \\
foot $(\mathrm{ft})$ & 0.3048 & meter $(\mathrm{m})$ \\
mile (mi) & 1.609 & kilometer $(\mathrm{km})$ \\
\hline \multicolumn{3}{c}{ Area } \\
\hline square mile $\left(\mathrm{mi}^{2}\right)$ & 259.0 & \\
square mile $\left(\mathrm{mi}^{2}\right)$ & 2.590 & hectare $(\mathrm{ha})$ \\
\hline & Volume & \\
\hline cubic foot $\left(\mathrm{ft}^{3}\right)$ & 28.32 & cubic decimeter $\left(\mathrm{dm}^{3}\right)$ \\
cubic foot $\left(\mathrm{ft}^{3}\right)$ & 0.02832 & cubic meter $\left(\mathrm{m}^{3}\right)$ \\
\hline & Flow rate & \\
\hline cubic foot per second $\left(\mathrm{ft}^{3} / \mathrm{s}\right)$ & 0.02832 & cubic meter per second $\left(\mathrm{m}^{3} / \mathrm{s}\right)$ \\
\hline
\end{tabular}

Vertical coordinate information is referenced to the North American Vertical Datum of 1988 (NAVD 88).

Horizontal coordinate information is referenced to North American Datum of 1983 (NAD 83).

Altitude, as used in this report, refers to distance above the vertical datum. 


\title{
Two-Dimensional Flood-Inundation Model of the Flint River at Albany, Georgia
}

\author{
By Jonathan W. Musser and Thomas R. Dyar
}

\section{Abstract}

Potential flow characteristics of future flooding along a 4.8-mile reach of the Flint River in Albany, Georgia, were simulated using recent digital-elevation-model data and the U.S. Geological Survey finite-element surface-water modeling system for two-dimensional flow in the horizontal plane (FESWMS-2DH). Simulated inundated areas, in 1-foot (ft) increments, were created for water-surface altitudes at the Flint River at Albany streamgage (02352500) from 192.5-ft altitude with a flow of 123,000 cubic feet per second $\left(\mathrm{ft}^{3} / \mathrm{s}\right)$ to 179.5 -ft altitude with a flow of $52,500 \mathrm{ft}^{3} / \mathrm{s}$. The model was calibrated to match actual floods during July 1994 and March 2005 and Federal Emergency Management Administration floodplain maps. Continuity checks of selected stream profiles indicate the area near the Oakridge Drive bridge had lower velocities than other areas of the Flint River, which contributed to a rise in the flood-surface profile. The modeled inundated areas were mapped onto monochrome orthophoto imagery for use in planning for future floods. As part of a cooperative effort, the U.S. Geological Survey, the City of Albany, and Dougherty County, Georgia, conducted this study.

\section{Introduction}

The U.S. Geological Survey (USGS), the City of Albany, and Dougherty County, Georgia, are cooperating on floodplain studies along the Flint River at Albany, Georgia (fig. 1). Since 1994, the City of Albany has experienced two major floods. During July 1994, Tropical Storm Alberto caused recordbreaking flooding in most of the Flint River Basin. The maximum flood flow in Albany was about 123,000 cubic feet per second $\left(\mathrm{ft}^{3} / \mathrm{s}\right)$ at an altitude of about $192.5 \mathrm{feet}(\mathrm{ft})$ at the USGS Albany streamgage (02352500) at the Norfolk Southern Railroad bridge (fig. 2). The probable recurrence interval (RI) of the flood was estimated to be about 200-300 years (Stamey, 1996). The flood inundated a large part of Albany, caused widespread community infrastructure and property damage, affected public safety and health, and required the evacuation of about 75,000 people. Floodwaters at Albany remained above the 100-year flood stage, about 187.5-ft altitude, for 7 days. The second major flood, during March 1998, resulted from a regional winter storm, which also caused substantial flooding at Albany and required the evacuation of about 14,000 people. This flood was estimated to have about a 70 -year RI, about $86,100 \mathrm{ft}^{3} / \mathrm{s}$ flow, with a flood altitude of about 186.5-ft altitude (Stamey and Hess, 1993).
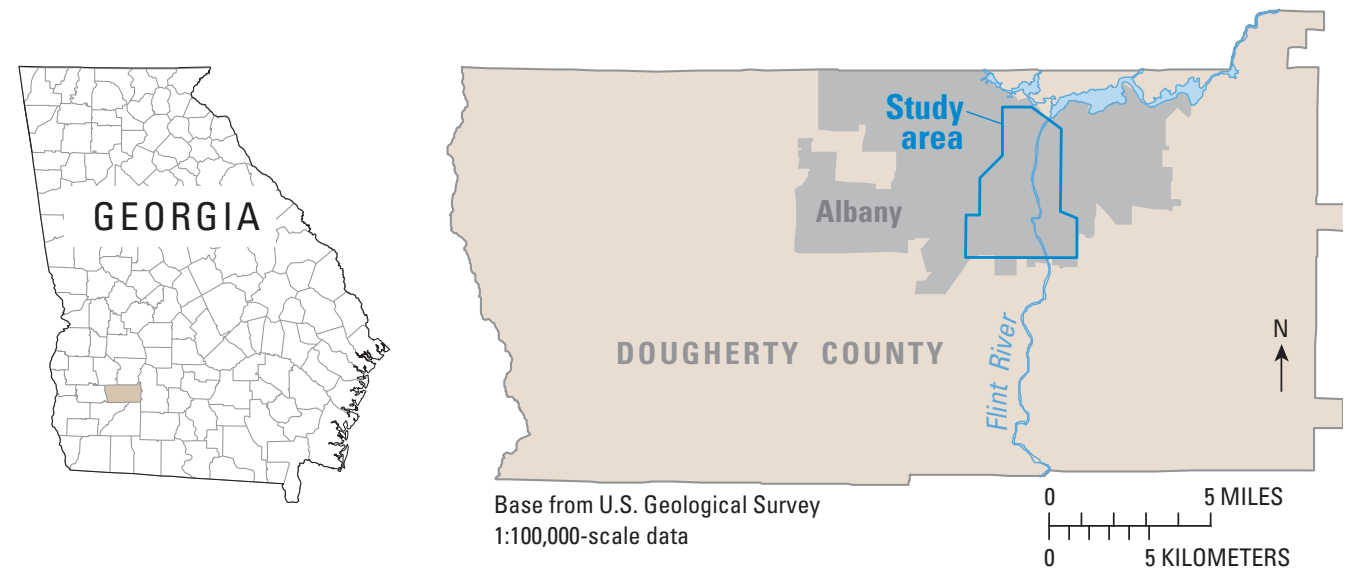

Figure 1. Location of two-dimensional model study area along the study reach of the Flint River at Albany, Georgia. 


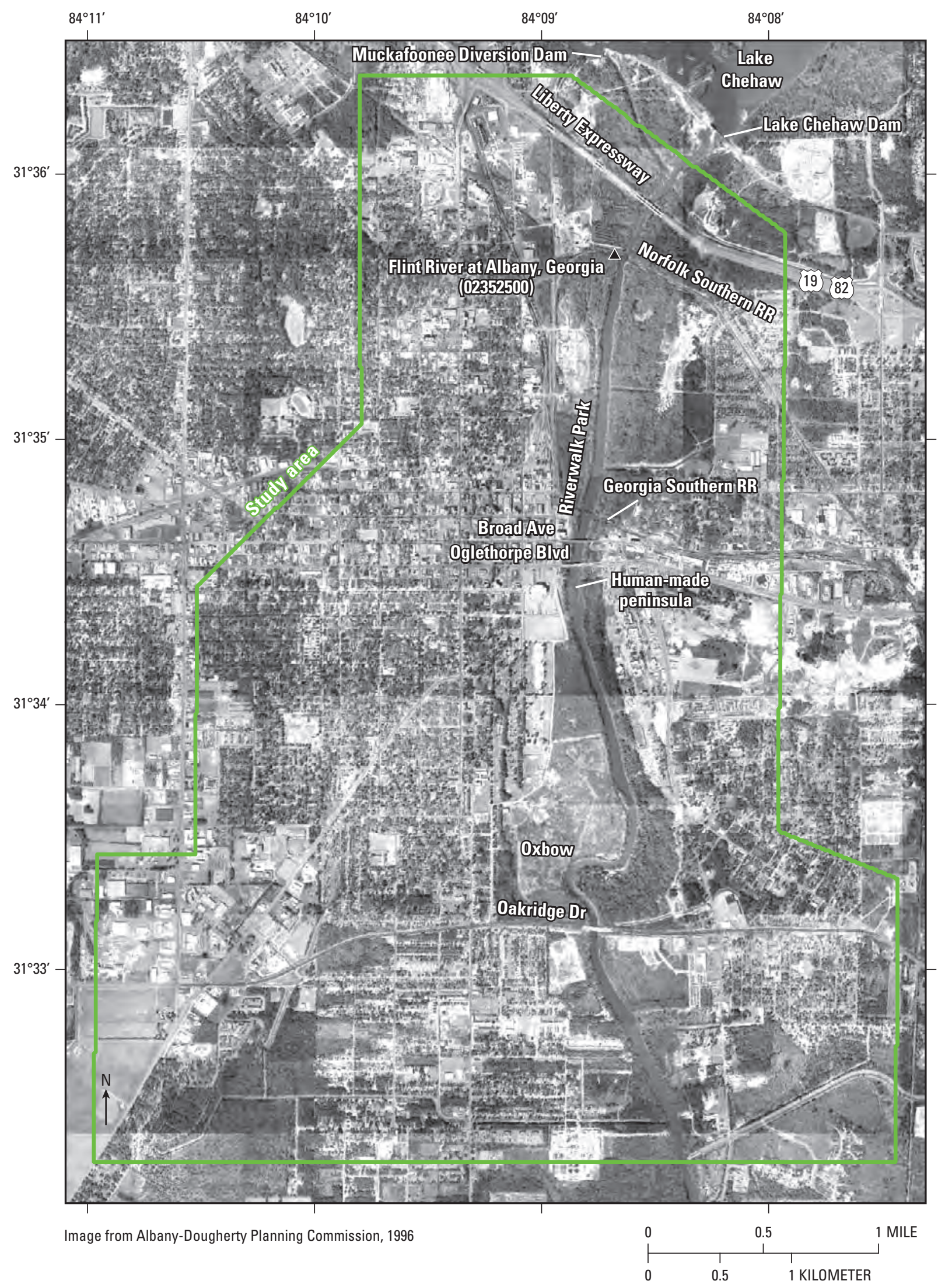

Figure 2. Flood-inundation study area showing all major Flint River crossings, Albany, Georgia. [RR, Railroad] 
Albany is growing rapidly and has a number of active community improvement projects. Some of the projects, such as the planned 8.5-mile (mi) extension to the new Riverwalk along the west bank of the Flint River, may improve floodwater conveyance in the study reach. In the 1998 Governor's Task Force on Reducing the Impacts of Flooding in the Flint River Basin, Preliminary Report (Georgia Emergency Management Agency and the Georgia Department of Natural Resources, 1998), reexamination of the river basin development plans and flood mitigation infrastructure was cited as a principal need. The report concluded flood improvements-including the repair and replacement of the 250 failed dams, numerous roadways and bridges, as a result of Tropical Storm Alberto-needed to be factored into reexamination of the Flint River Basin. Development of a metropolitan area can result in changing flood frequency and higher flood peaks for areas downstream (Konrad, 2003). The rapid development of the Atlanta area could have this kind of impact on the Flint River at Albany. In response to past flooding and the possibility of future flooding, the City of Albany and Dougherty County are cooperating with the USGS in the development of a model to map the extent of flooding in Albany from the Flint River. The USGS monitors streamflow conditions throughout the Flint River Basin (fig. 3). The cooperative effort between the City of Albany, Dougherty County, and the USGS will assist the community in planning for future floods as well as emergency response during future floods. With a National Weather Service forecast, the city and county emergency response groups will be able to assess what areas will require their assistance during a flood.

\section{Purpose and Scope}

The purpose of this report is to describe the procedure and results of a study to create 1-ft-interval flood-inundation maps of the Flint River in Albany, Georgia. The scope of the work included field examination of the study area (fig. 1); mapping of eight river cross sections; delineating land-use areas for about 13.7 square miles $\left(\mathrm{mi}^{2}\right)$; and applying a twodimensional finite-element model (FESWMS-2DH) covering the Flint River near Albany from about 0.2 mi south of Lake Chehaw to about $1.1 \mathrm{mi}$ south of Oakridge Drive. When the model was completed, field checks were completed for the flood-inundation extent at nine locations, as well as presentation of maps of the model results.

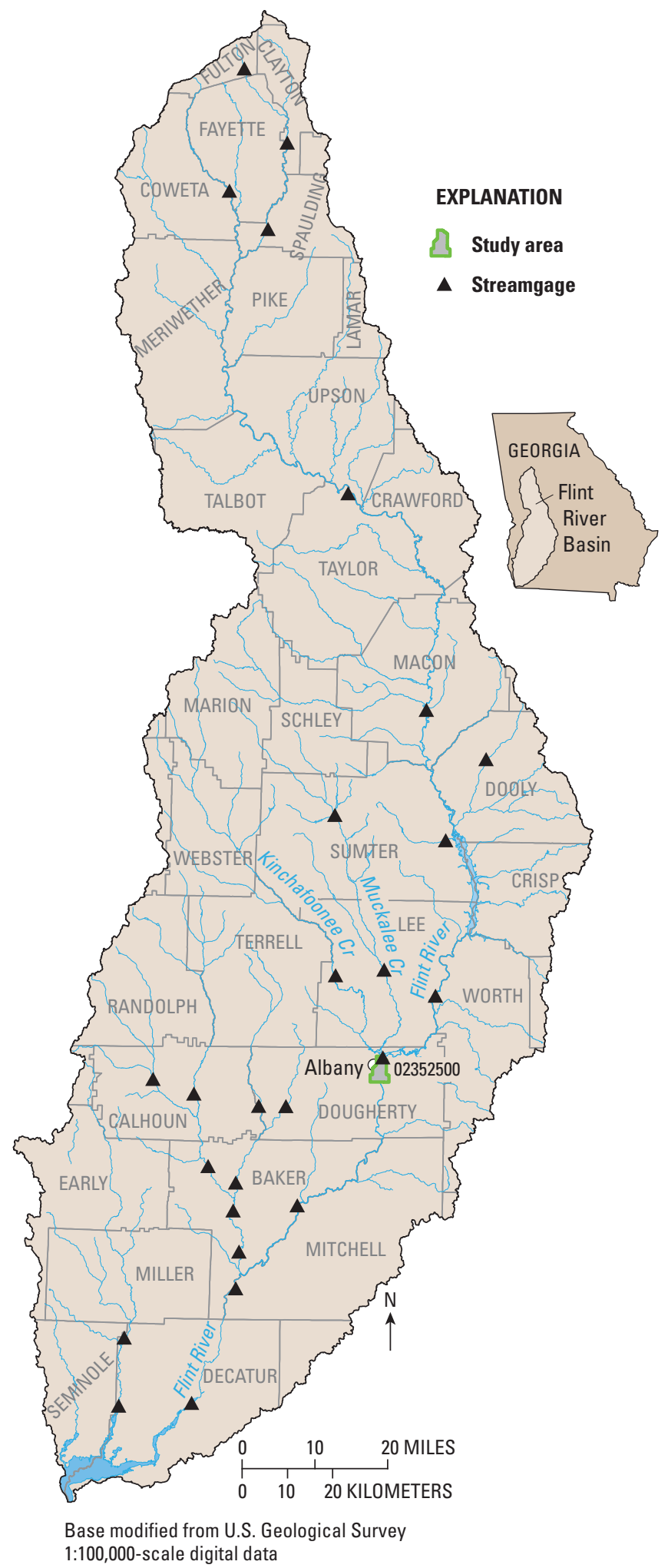

Figure 3. U.S. Geological Survey streamgages in the Flint River Basin, Georgia. 


\section{Description of Study Area}

In the Albany area, the natural state of the Flint River has been changed by the construction of dams, a human-made peninsula, and numerous bridges (fig. 2). The northern part of the area includes the Muckafoonee Diversion Dam, which impounds Muckalee and Kinchafoonee Creeks at low and medium flows. The area also includes Lake Chehaw Dam (a Georgia Power Company facility), which regulates the combined flows of the Flint River (drainage area 4,190 $\mathrm{mi}^{2}$ ), Kinchafoonee Creek (drainage area $658 \mathrm{mi}^{2}$ ), and Muckalee Creek (drainage area $443 \mathrm{mi}^{2}$ ). The recreation area around Lake Chehaw is being connected to downtown Albany via the development of Riverwalk Park. From Lake Chehaw Dam, the Flint River passes under five highway and two railroad bridges as shown in figure 2. (The Liberty Expressway crossing is composed of two bridges.) In addition to the river community infrastructure, there are two natural features that substantially affect flood flows in the study reach. The natural river constriction in Albany is most evident near the downtown Broad Avenue and Oglethorpe Boulevard bridges. The river flow through this area is also limited by a human-made peninsula about $500 \mathrm{ft}$ downstream from the Oglethorpe Boulevard bridge. This peninsula is an area of the channel filled in from the east bank of the river, and is visible at low flows. During high flows, the peninsula creates a large amount of turbulence. The second natural feature is the river oxbow near Oakridge Drive (fig. 2). Both features constrain flood flow through Albany. The community infrastructure-including dams, roadway embankments, and bridges - tends to further hinder flood flows through Albany. Of these features, the most influential on extreme high flows is the river constriction at Broad Avenue and Oglethorpe Boulevard. The Riverwalk Park, which is being constructed on the west bank of the river, may reduce roughness and improve conveyance, thereby improving flood flows.

\section{Previous Studies}

Previous studies include a flood insurance study for Dougherty County and incorporated areas (Federal Emergency Management Agency, 2001), and a Section 205 detailed project report and environmental assessment for Kinchafoonee Creek and Hogpen Ditch at Albany (U.S. Army Corps of Engineers, 1997). The U.S. Army Corps of Engineers (USACE) completed a Section 205 detailed project report for the Flint River at Albany (U.S. Army Corps of Engineers, 2002), which included simulation of the Flint River at Albany. The USACE study involved usage of the one-dimensional step-backwater model HEC-2, developed by the Hydrologic Engineering Center in Davis, California (U.S. Army Corps of Engineers, 1990). The HEC-2 model was calibrated to high watermarks from the July 1994 Tropical Storm Alberto flood.

\section{Method of Study}

The current study included field investigations, review of previous studies, data acquisition, and model development. Numerous field visits were required to obtain sufficient site information, flood and flood-damage history, bridge-structure characteristics, stream cross sections, and land-cover characteristics.

The study was performed in several stages:

1. Data necessary for the model were obtained including ground-surface altitude, orthophoto imagery, river cross sections, bridge geometry, floodplain boundaries, and land use.

2. A finite-element surface-water inundation model was constructed using Surface Water Modeling System (SMS) (Environmental Monitoring Systems, Incorporated, 2006) and FESWMS-2DH (U.S. Geological Survey, 2006).

3. Different model scenarios were run, and results were obtained for each 1 -ft interval.

4. Model results were mapped onto the imagery with floodplain boundaries and other pertinent information (R.W. Weathersby, GIS Specialist, Monochrome Imagery of Albany and Dougherty County, Albany and Dougherty County Planning and Development Services, written commun., 2003).

5. Problem areas were identified where the model could be used to study the effects of changes along the river.

\section{Acknowledgments}

The technical assistance of Randy Weathersby, Elizabeth Dean, and Tracy Hester from the Albany and Dougherty County Planning and Development Services is greatly appreciated. 


\section{Two-Dimensional Flood- Inundation Model}

The two-dimensional flood surfaces for the Flint River floodplain at Albany were used to develop the USGS twodimensional, steady-state flow model based on finite-element principles (FESWMS-2DH) (U.S. Geological Survey, 2006), along with SMS (Environmental Modeling Systems, Incorporated, 2006). Flood surfaces, in 1-ft increments, were developed that correspond to streamflow values from gage heights at the USGS Albany streamgage (fig. 2; 02352500) from about $30 \mathrm{ft}$ (or $179.5 \mathrm{ft}$ NAVD 88, just below the 10-year recurrence interval flood) to about $43 \mathrm{ft}$ (or $192.5 \mathrm{ft}$, the peak altitude for Tropical Storm Alberto during July 1994). These surfaces were printed over 1 - $\mathrm{ft}$ resolution gray-scale digital orthophotos (R.W. Weathersby, GIS Specialist, Monochrome Imagery of Albany and Dougherty County, Albany and Dougherty County Planning and Development Services, written commun., 2003). The USGS streamgage (02352500) at Albany is a National Weather Service flood-forecast location, and flood-forecast predictions are indexed to gage heights at the streamgage (the difference between streamgage stage and water-surface altitude is $149.5 \mathrm{ft}$ ). In addition to the flood-extent information provided by this effort, depth, velocities, sectional-flow and flow-direction vectors were calculated. These hydraulic data can be displayed and used to develop warnings and hazard scales for a flood.

The mesh for the model was initially designed as a 120 -ft square grid to ensure equal resolution across the study area. During model development, it was determined that the area along the Flint River required a more detailed mesh with cells of about $20 \mathrm{ft}$ by $40 \mathrm{ft}$, because of high flow volumes and velocities, steep bank slopes, and the presence of bridge structures (fig. 4). The cells on the outside of the river channel were transitioned into the square grid cells across the rest of the study area. Altitude was obtained from the City of Albany as point data, and an altitude grid with $10-\mathrm{ft}$ horizontal cells was produced for input to the model. Cross sections of the stream channel were determined for the study reach and were georeferenced to the model. Additional altitude points were added to the altitude grid at a point just downstream from the Oglethorpe Boulevard bridge where a human-made peninsula was built into the river channel. A number of the square and rectangular cells in the mesh had an indefinite flow direction because they included two diagonal corners that are higher than the other two corners, which could result in two different flow directions. These cells were split into two triangular cells to alleviate this problem (Environmental Monitoring Systems, Incorporated, 2006).

All areas in the study reach were classified into five land-cover categories: clear (paved areas, fields, and grass areas), forest, low-density urban, high-density urban, and channel. Roughness coefficients (Manning's $n$ ), derived from Barnes (1967), were assigned to each land-cover category: clear- 0.03 , forest -0.13 , low-density urban -0.15 , highdensity urban- 0.20 , and the channel varied from 0.027 to 0.0415 . The calibrated model incorporates the effects of the partially completed (as of 2005) Riverwalk Park at Albany. The Riverwalk is a new park adjacent to the Flint River, and consists of green space and pedestrian walkways.

The boundary conditions used for the model are inflow volume and outflow altitude. The inflow boundary is located at the edge of the model mesh downstream from the Lake Chehaw Dam and the Muckafoonee Diversion Dam. The outflow boundary is located on the south edge of the model mesh where the outflow boundary altitude is higher than groundsurface altitude. As the outflow boundary altitude changes, the location of outflow boundary is adjusted. To obtain a stable solution, initial model boundaries must be set to a no-flow condition with a constant water level across the entire mesh. Boundary conditions are then slowly adjusted to their final values. Initial boundary conditions used to start the model were an inflow of $0 \mathrm{ft}^{3} / \mathrm{s}$ and an outflow altitude of $231 \mathrm{ft}$. Through an iterative process, the inflow was increased gradually to $123,000 \mathrm{ft}^{3} / \mathrm{s}$, followed by a reduction of the outflow boundary condition altitude of $184.5 \mathrm{ft}$. This altitude was obtained from the USACE (2002) Flint River report. Following adjustment of boundary conditions, bridge piers and deck altitudes for the five highway bridges (two at Liberty Expressway) and two railroad bridges were input to the model. Cells in the study area that were dry at this point were removed from the model, and the model was reconfigured to its final mesh configuration.

In the Albany area during Tropical Storm Alberto, a number of areas near the Flint River were inundated because of underground hydraulic connections, such as storm sewers and subsurface natural flow pathways. To show these lowlying areas, simulated river-surface altitudes were extended beyond the river banks. A number of these low areas with altitudes below the river-surface altitude also were mapped in figures A1-A14 (Appendix A). During the flood on March 30, 2005, a number of these low-lying areas were checked for flooding. No area more than $0.5 \mathrm{mi}$ from the river was found to be flooded, so the mapped low-lying areas are limited to an area within $0.5 \mathrm{mi}$ of the modeled flood area. 


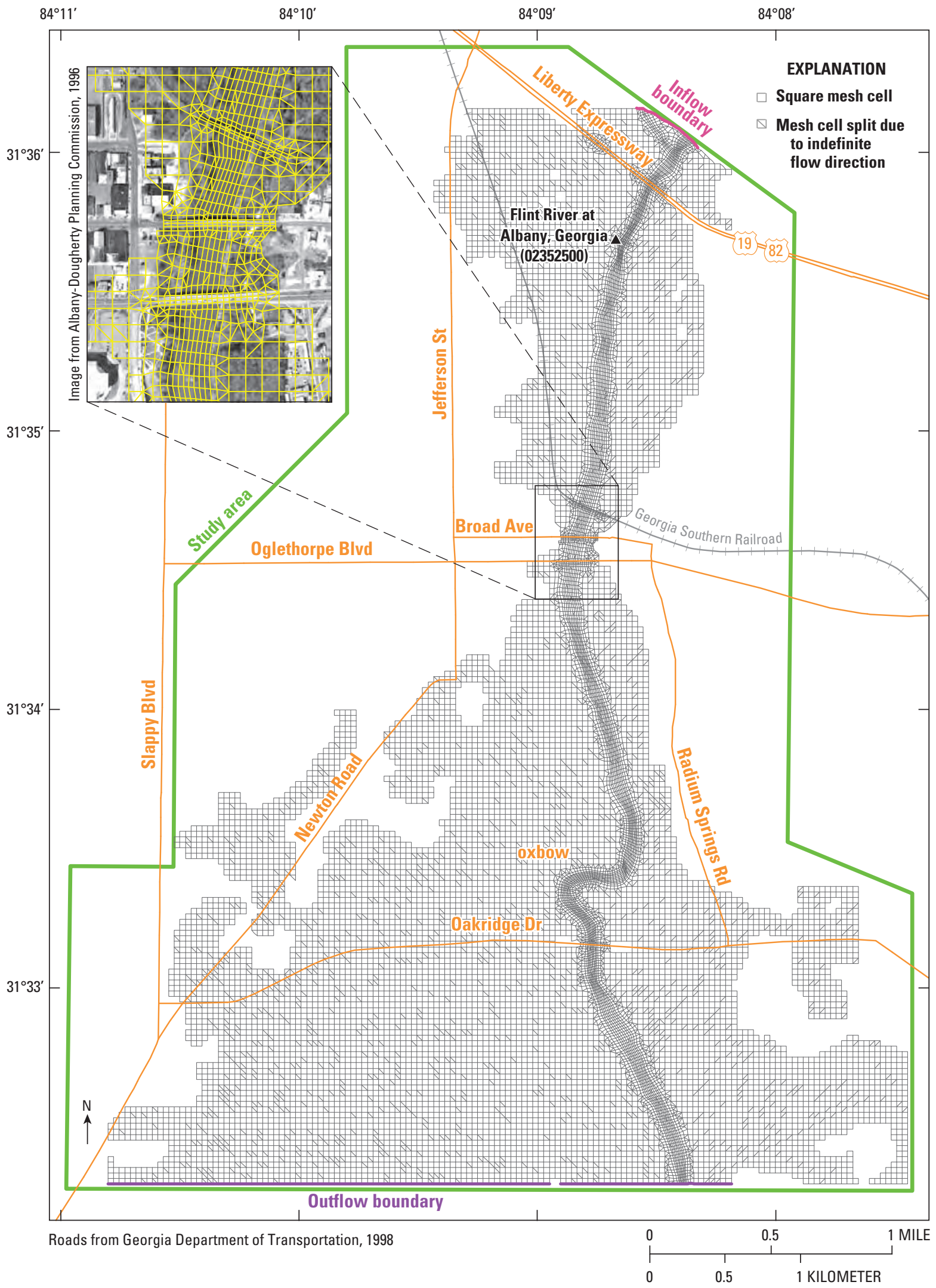

Figure 4. Finite-element mesh used for two-dimensional model of the Flint River at Albany, Georgia. Inflow and outflow boundary conditions are for a water-surface altitude of 192.5 feet at the Albany streamgage. 


\section{Model Calibration}

The model was calibrated to observed flooding from Tropical Storm Alberto during July 1994, and a smaller flood during March 2005. Initial model calibration involved running the model for the peak streamflow observed during the 1994 Tropical Storm Alberto flood, about 123,000 ft 3 s, which was estimated to have a recurrence interval of between 200 and 300 years. An adjustment of the channel roughness for the model was done until the water-surface altitude at the USGS Albany streamgage was $192.5 \mathrm{ft}$. The model essentially reproduced the measured Tropical Storm Alberto flood inundation, as indicated in the comparison of the model results with the Federal Emergency Management Agency (FEMA) floodplain at Albany shown in figure A14. The actual flood altitudes and simulated values are in close agreement as indicated by the position of the inundated area boundary between the 100- and the 500-year floodplain boundaries (fig. A14). Once the model was calibrated for the 192.5 -ft water-surface altitude at Albany, the inflow was gradually lowered to the value corresponding to an altitude of $191.5 \mathrm{ft}$. The outflow altitude was then gradually lowered to $183.5 \mathrm{ft}$ to represent the 1-ft incremental decrease in the water-surface altitude. Based on an earlier modeling study by the USACE (2002), an assumption was made that a 1-ft drop at the gage corresponded to a 1-ft drop at the outflow. Following adjustment of stage at the outflow boundary, the channel roughness value was adjusted until the model was at 191.5-ft altitude at the streamgage. This procedure was repeated for the rest of the water-surface altitudes down to the 179.5-ft altitude. The channel roughness ranged from 0.027 to 0.0415 . At the 192.5 -ft gage altitude, the model became unstable when the eddy viscosity was lowered below 6.5. As a result of this, channel roughness was used for model calibration and eddy viscosity was set at 6.5 .

A continuity check of the model was done for the $192.5-\mathrm{ft}$ altitude by dividing a cross section of the model into sections of about $20 \mathrm{ft}$. The width multiplied by the depth multiplied by the velocity gave the flow rate for that section. The section flows were then added together to form a total flow across the section. The resulting flow was $124,904 \mathrm{ft}^{3} / \mathrm{s}$, which is within 1.5 percent of $123,000 \mathrm{ft}^{3} / \mathrm{s}$, the model flow input for the 193-ft altitude. In addition, a continuity check was done at a cross section that included the Oakridge Drive bridge; the continuity check helped determine the percentage of water flowing under the Oakridge Drive bridge and the percentage flowing around it. The model indicated that $45,808 \mathrm{ft}^{3} / \mathrm{s}$ was flowing around the bridge and $74,466 \mathrm{ft}^{3} / \mathrm{s}$ was flowing under the bridge. The sum of these two flows is 2.2 percent different than the expected $123,000 \mathrm{ft}^{3} / \mathrm{s}$, which can probably be attributed to the unstable nature of the model in the vicinity of the bridge. In terms of percentages, only 62 percent of the flow at this water-surface altitude is directed under the Oakridge Drive bridge, with 38 percent of the flow directed around the bridge.

On March 30, 2005, a field check of simulated and measured flood extents was done using a flood at about $182-\mathrm{ft}$ altitude. The actual flood extent at multiple sites along the model reach was checked against simulated values. In all locations, the measured extent confirmed the boundary that was simulated by the model. Selected photographs of the sites that were checked and their locations are shown in Appendix B. 


\section{Simulated Flood Inundation}

A series of simulated flood inundation maps was prepared to assist planners and emergency personnel in dealing with flood depth hazards from future floods. The extent of the inundated areas is shown in Appendix A (figs. A1-A14). The depth of water-which is categorized into three flood depth hazard: less than $1 \mathrm{ft}$; between 1 and $3 \mathrm{ft}$; and greater than $3 \mathrm{ft}$-also is shown in Appendix A (figs. A15-A28). About $4.8 \mathrm{mi}$ of the Flint River at Albany were included within the model. At a flood altitude of $179.5 \mathrm{ft}$, about $1.5 \mathrm{mi}^{2}$ were simulated as being inundated and at a flood altitude of $192.5 \mathrm{ft}$, about $5.9 \mathrm{mi}^{2}$ were inundated.

The simulated velocity magnitude of the area around the Oakridge Drive bridge is shown in figure 5. A substantial drop in velocity is evident upstream from the bridge. The drop in velocity occurs because of the effects of the highway embankment, the bridge, and the nearby Flint River channel oxbow. Selected simulated flow profiles along the river for the area of the model are shown in figure 6 . The flow profile upstream from the Oakridge Drive bridge has leveled, or in some cases increased. This corresponds with the area of lower velocities shown in figure 5. These model results support the findings described in the USACE (2002) Flint River report, concerning modifications of the channel floodway upstream and downstream from the bridge. Likewise, the model could be configured to simulate the effects of changes in the floodplain, such as modifications to the channel or expansion of the Riverwalk Park.

\section{Model Limitations}

The results of this study could differ from actual flood results for several reasons. The model is based on a steadystate constant flow and does not account for rising or falling flow values or for any inflow into the system from sources other than the Flint River. The boundary condition at the outflow is assumed to be a constant value across the entire southern edge of the mesh, and these values are not known precisely. Finally, the discretization of the altitude and the mesh causes the model to be an approximation of the actual conditions in the area.

\section{Summary}

Potential flow characteristics of future flooding along a 4.8-mile reach of the Flint River in Albany, Georgia, were simulated using recent digital-elevation-model data and the U.S. Geological Survey (USGS) finite-element surface-water modeling system for two-dimensional flow in the horizontal plane (FESMWS-2DH). Results of the study-conducted by the USGS in cooperation with the City of Albany and Dougherty County, Georgia - are being used by the local community to plan for future floods.

Information on land-surface altitude, orthophoto imagery, river cross sections, bridge geometry, floodplain boundaries, and land use were compiled into a Geographic Information System to facilitate model development. A finite-element mesh for the model was created using the land-surface altitude and river cross-section data. Land-use data were used for categorizing areas for roughness coefficients, and bridge geometry was entered into the model. The model was calibrated to a peak flow of 123,000 cubic feet per second ( $\left.\mathrm{ft}^{3} / \mathrm{s}\right)$ at a water-surface altitude of 192.5 feet (ft) at the Flint River at Albany, Georgia, streamgage (02352500), and was gradually reduced at 1-ft increments to a flow of 52,500 ft $3 / \mathrm{s}$ and a water-surface altitude of $179.5 \mathrm{ft}$. Floodplains were mapped over orthophoto imagery to show the floodplain extent as well as the water depth. Simulated flow velocities upstream from the Oakridge Drive bridge indicated an area of decreased velocity, and water-surface altitude profiles in this area indicated a leveling or slight increase in the water surface upstream from the bridge. 

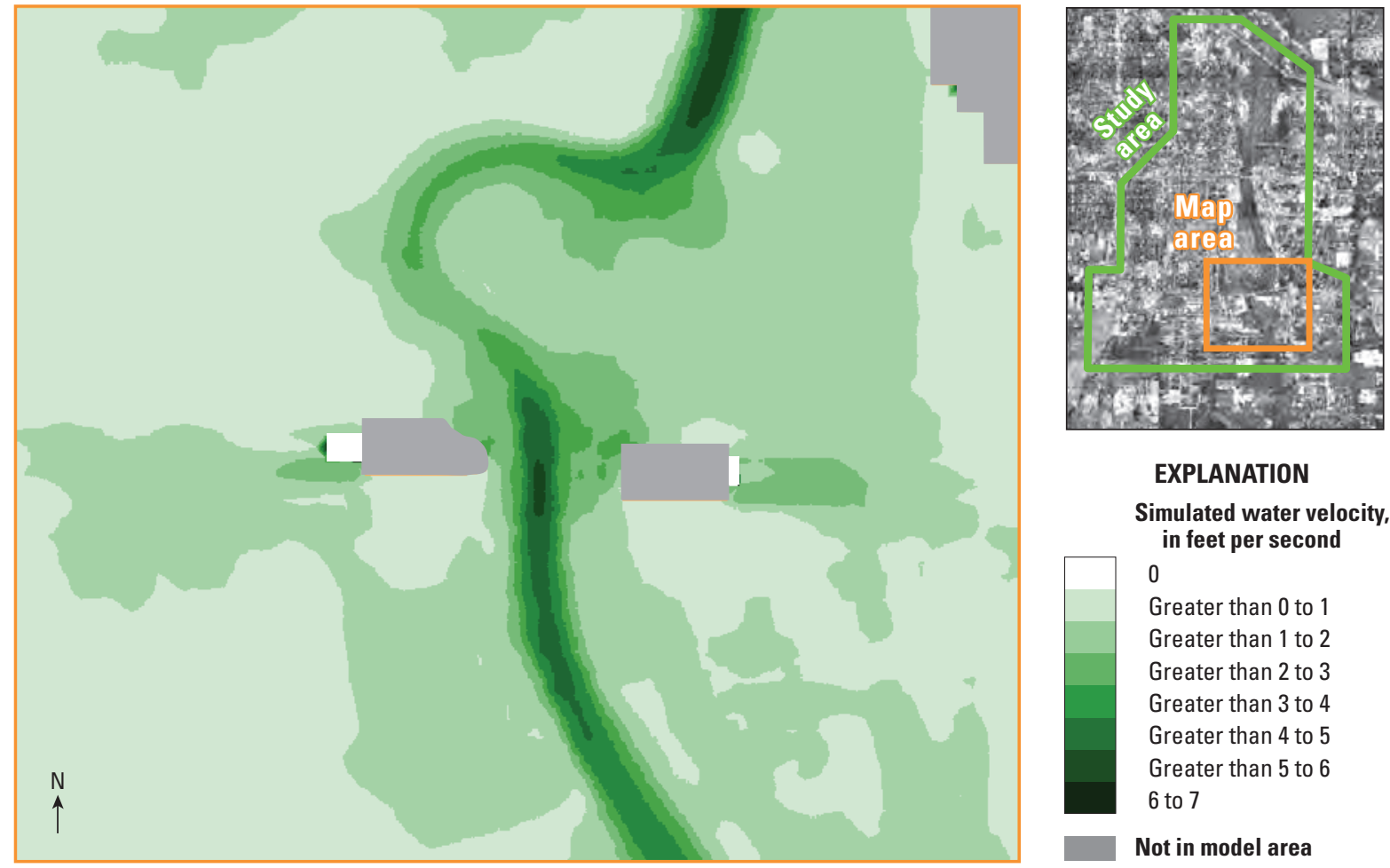

EXPLANATION

Simulated water velocity, in feet per second 0

Greater than 0 to 1

Greater than 1 to 2

Greater than 2 to 3

Greater than 3 to 4

Greater than 4 to 5

Greater than 5 to 6

6 to 7

Figure 5. Velocity distribution of the Flint River near Oakridge Drive at Albany, Georgia.

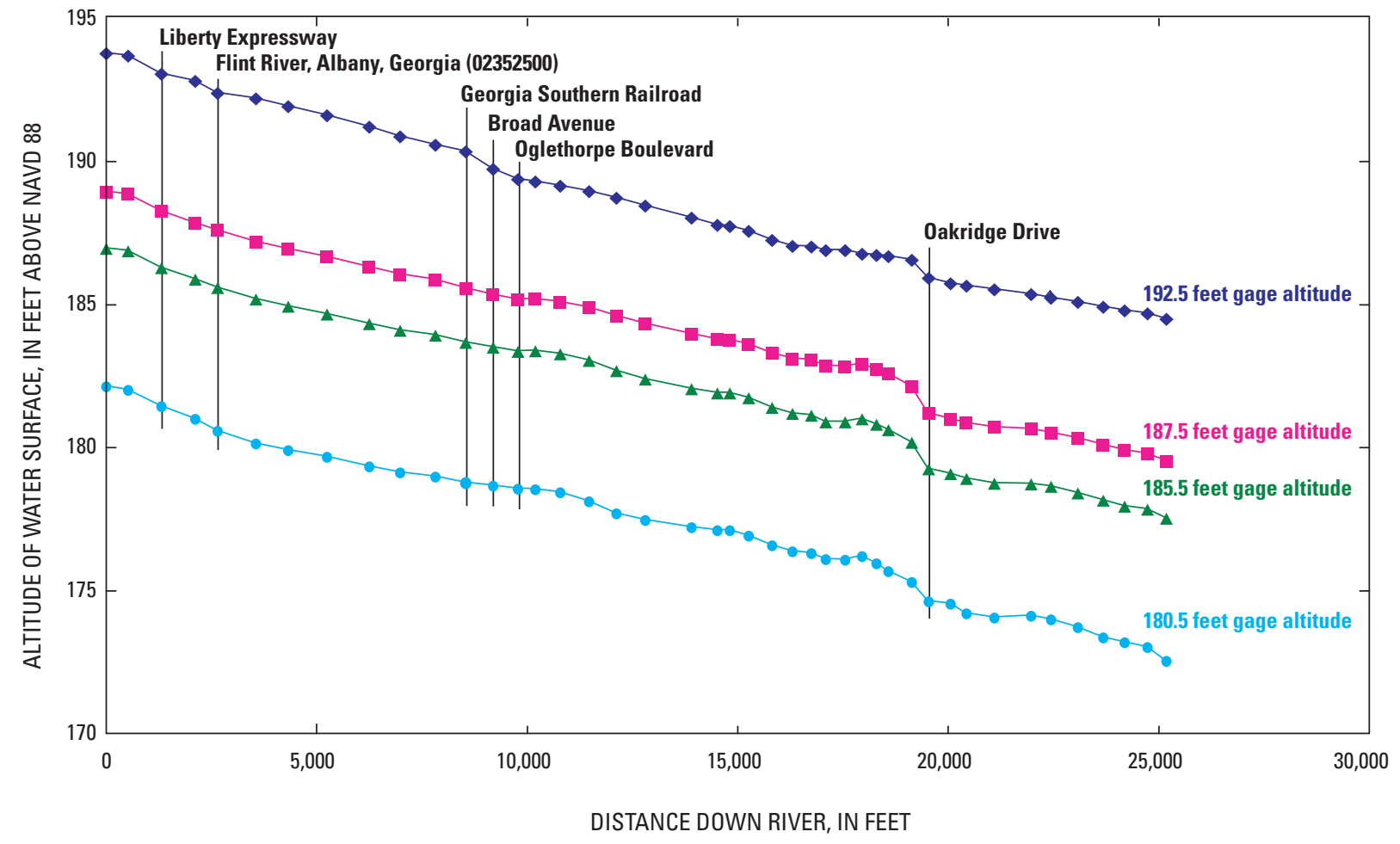

Figure 6. Simulated flow profiles by streamgage altitude in model area for the Flint River at Albany, Georgia (see figure 4 for location). 


\section{References Cited}

Barnes, H.H., 1967, Roughness characteristics of natural channels: U.S. Geological Survey Water-Supply Paper 1849, 213 p., available online at http://pubs.usgs. gov/wsp/wsp_1849/.

Environmental Monitoring Systems, Incorporated, 2006, Surface-water Modeling System (SMS): South Jordan, Utah, accessed September 2006, at http://www.ems-i.com.

Federal Emergency Management Agency, 2001, Flood insurance study for Dougherty County, Georgia, and incorporated areas, 29 p.

Georgia Emergency Management Agency and the Georgia Department of Natural Resources, 1998, The Governor's Task Force on Reducing the Impacts of Flooding in the Flint River Basin, Preliminary Report, 22 p.

Konrad, C.P., 2003, Effects of urban development on floods: U.S. Geological Survey Fact Sheet 076-03, 4 p., available online at http://pubs.usgs.gov/fs/fs07603/.

Stamey, T.C., 1996, Summary of data-collection activities and effects of flooding from Tropical Storm Alberto in parts of Georgia, Alabama, and Florida, July 1994: U.S. Geological Survey Open-File Report 96-228, 23 p., available online at http://pubs.usgs.gov/of/1996/ofr96-228/.
Stamey, T.C., and Hess, G.W., 1993, Techniques for estimating magnitude and frequency of floods in rural basins of Georgia: U.S. Geological Survey Water-Resources Investigations Report 93-4016, 75 p., available online at http://pubs.er.usgs.gov/usgspubs/wri/wri934016

U.S. Army Corps of Engineers, 1990, HEC-2 water surface profiles, User's manual: Davis, California, Hydrologic Engineering Center, variable pagination

U.S. Army Corps of Engineers, Mobile District, 1997, Section 205 detailed project report and environmental assessment, Kinchafoonee Creek and Hogpen Ditch, Albany, Georgia: Mobile, Alabama, various pagination.

U.S. Army Corps of Engineers, Mobile District, 2002, Section 205 detailed project report, Flint River Albany, Georgia: Mobile, Alabama, various pagination.

U.S. Geological Survey, Finite-element surface-water modeling system for two-dimensional flow in the horizontal plane (FESWMS-2DH), accessed September 2006, at http://water.usgs.gov/software/feswms.html. 
Appendix A. Images showing simulated flood inundation and hazard scale at the Albany streamgage compared with Federal Emergency Management Agency's Digital Flood Insurance Rate Maps for the Flint River in Albany, Georgia, 1998 


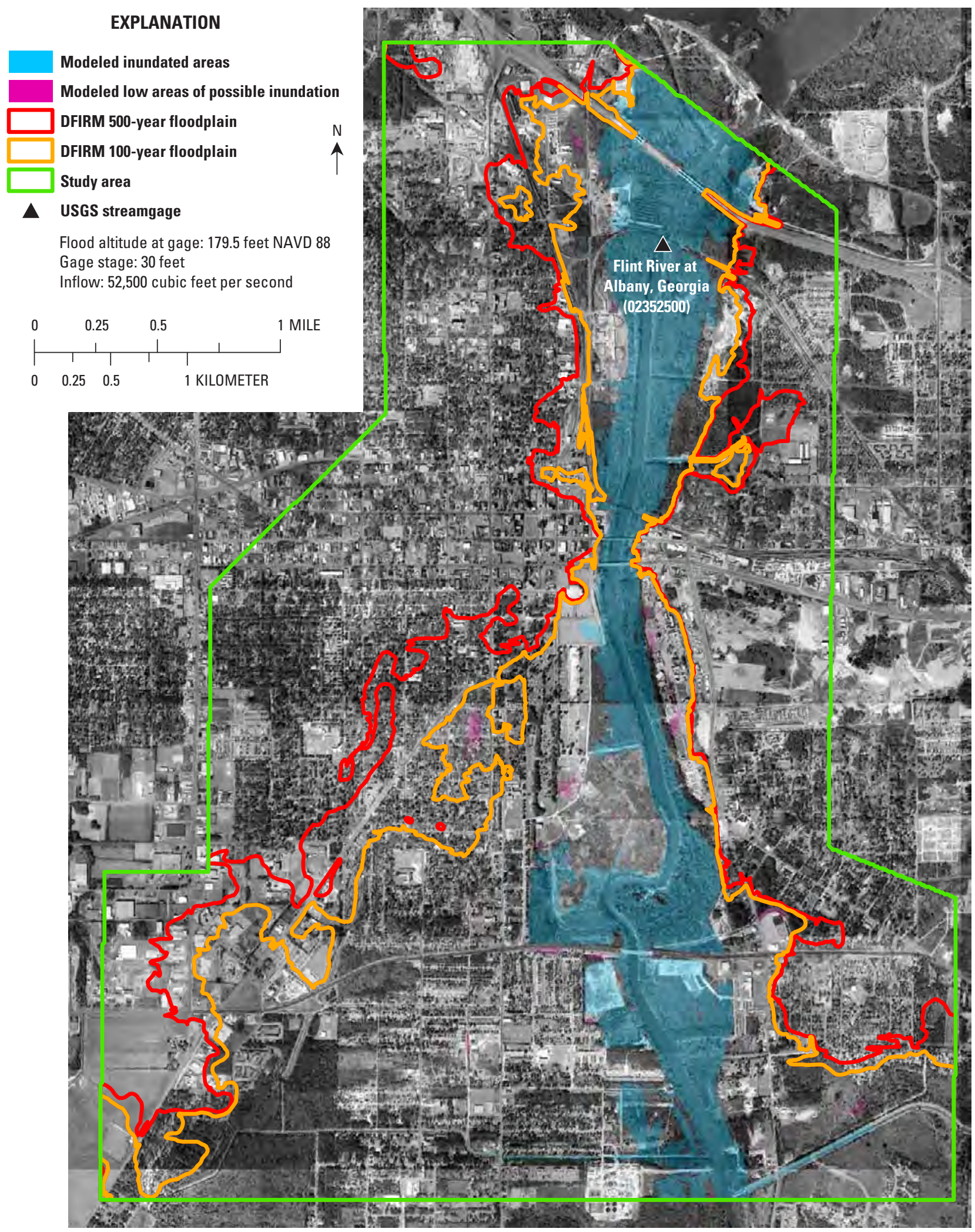

Image from Albany-Dougherty Planning Commission, 1996

Figure A1. Simulated flood inundation for a water-surface altitude of 179.5 feet at the Albany streamgage compared with Federal Emergency Management Agency's Digital Flood Insurance Rate Maps (DFIRM) for the Flint River in Albany, Georgia, 1998. 
EXPLANATION

Modeled inundated areas

Modeled low areas of possible inundation

DFIRM 500-year floodplain

DFIRM 100-year floodplain

Study area

- USGS streamgage

Flood altitude at gage: 180.5 feet NAVD 88 Gage stage: 31 feet

Inflow: 56,700 cubic feet per second

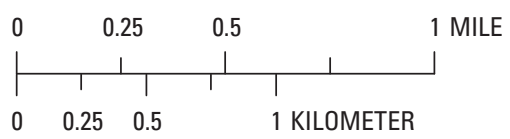
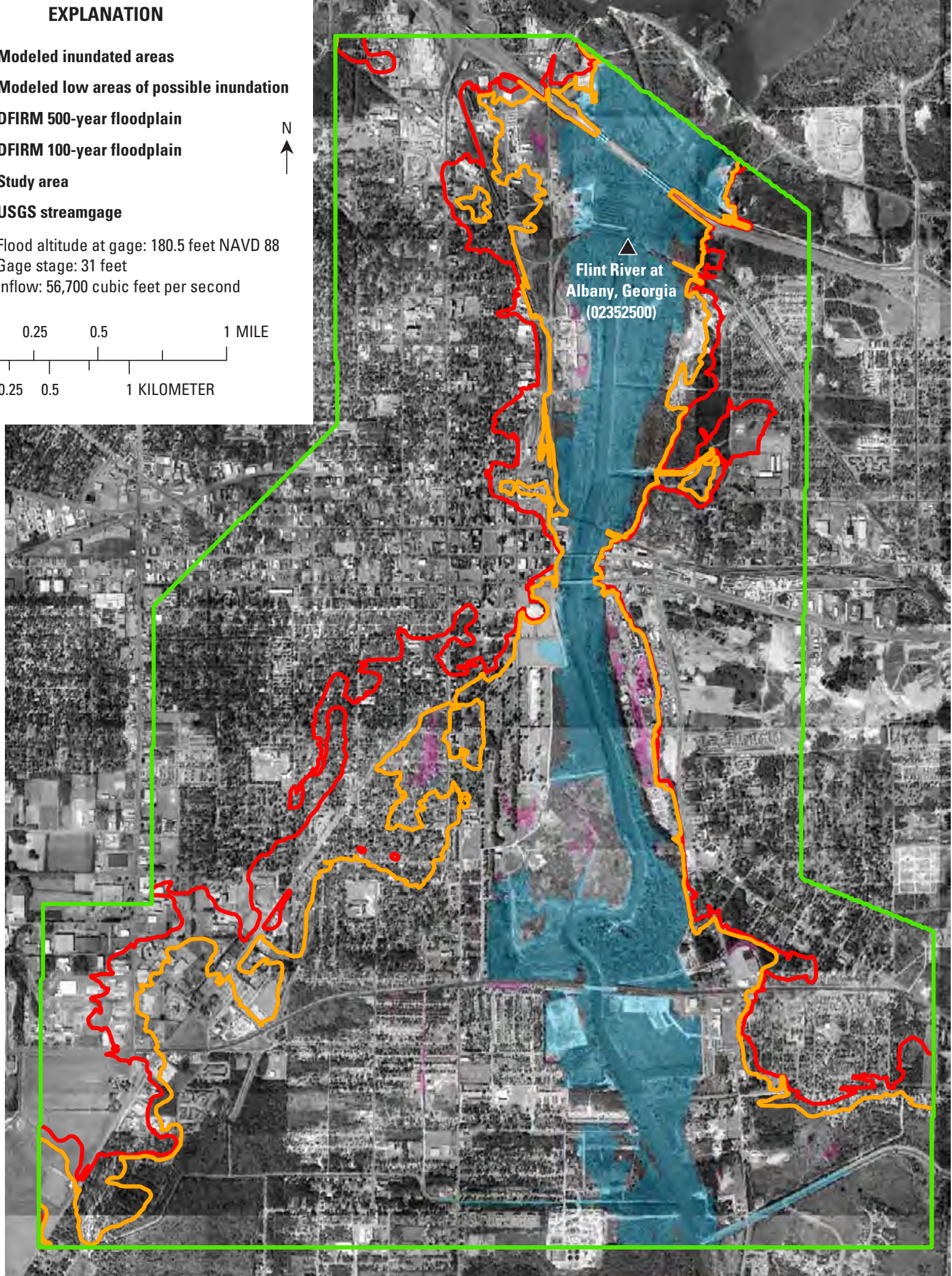

Image from Albany-Dougherty Planning Commission, 1996

Figure A2. Simulated flood inundation for a water-surface altitude of 180.5 feet at the Albany streamgage compared with Federal Emergency Management Agency's Digital Flood Insurance Rate Maps (DFIRM) for the Flint River in Albany, Georgia, 1998. 


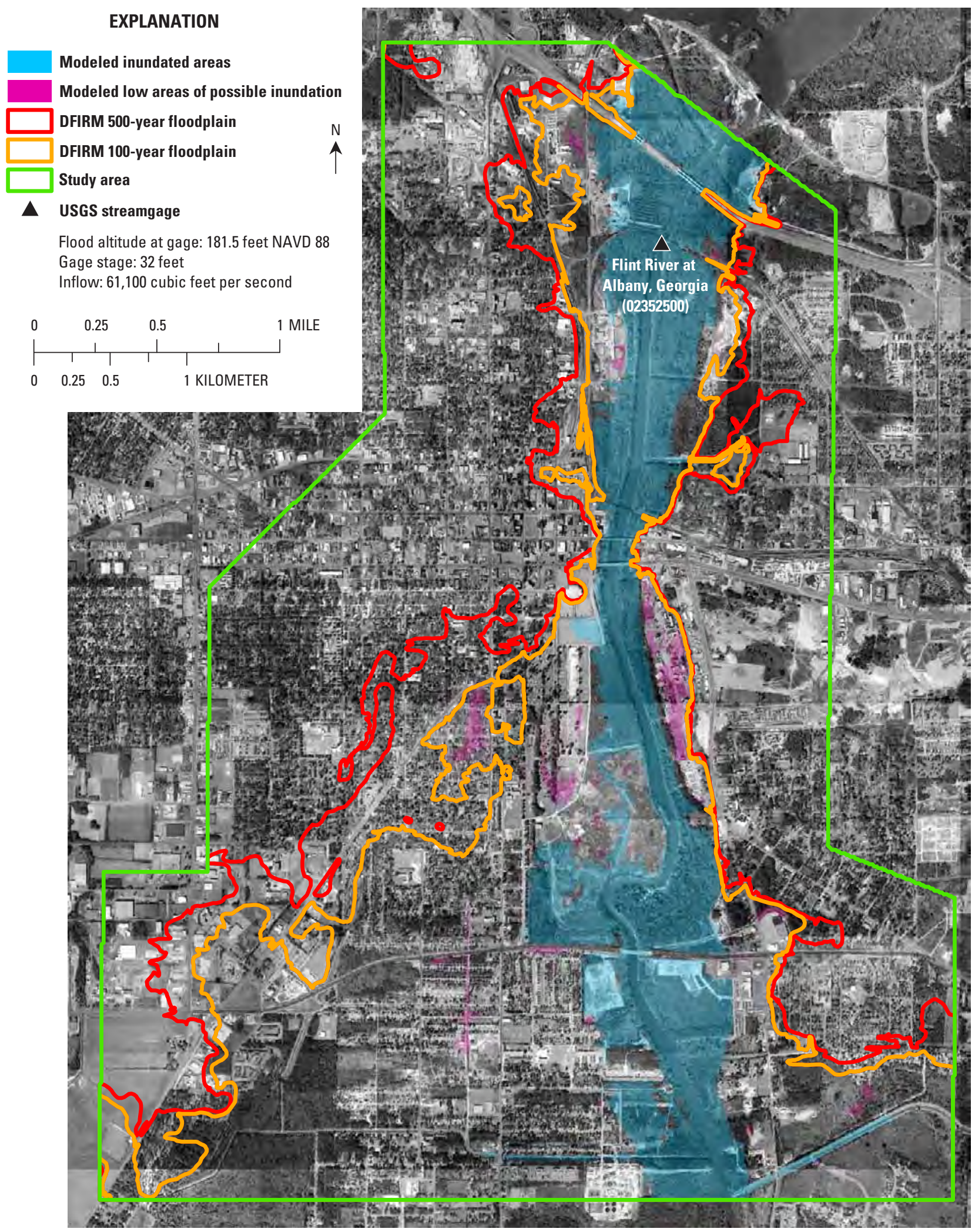

Image from Albany-Dougherty Planning Commission, 1996

Figure A3. Simulated flood inundation for a water-surface altitude of 181.5 feet at the Albany streamgage compared with Federal Emergency Management Agency's Digital Flood Insurance Rate Maps (DFIRM) for the Flint River in Albany, Georgia, 1998. 


\section{EXPLANATION}

Modeled inundated areas

Modeled low areas of possible inundation DFIRM 500-year floodplain DFIRM 100-year floodplain Study area

- USGS streamgage

Flood altitude at gage: 182.5 feet NAVD 88 Gage stage: 33 feet

Inflow: 65,600 cubic feet per second

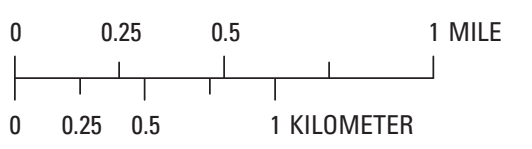

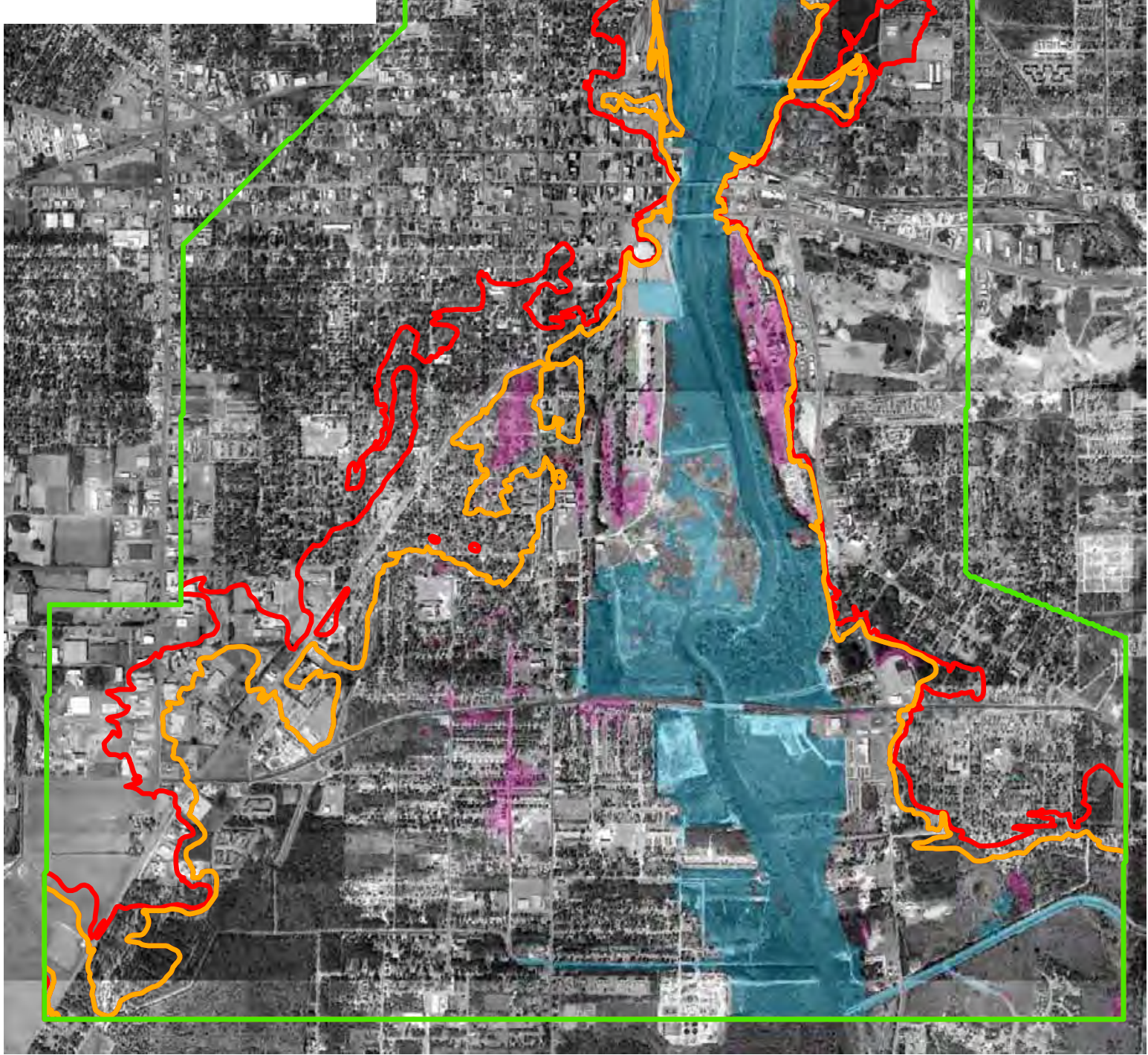

Image from Albany-Dougherty Planning Commission, 1996

Figure A4. Simulated flood inundation for a water-surface altitude of 182.5 feet at the Albany streamgage compared with Federal Emergency Management Agency's Digital Flood Insurance Rate Maps (DFIRM) for the Flint River in Albany, Georgia, 1998. 


\section{EXPLANATION}

Modeled inundated areas

Modeled low areas of possible inundation

DFIRM 500-year floodplain

DFIRM 100-year floodplain

Study area

- USGS streamgage

Flood altitude at gage: 183.5 feet NAVD 88 Gage stage: 34 feet

Inflow: 70,400 cubic feet per second

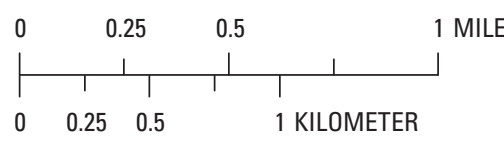

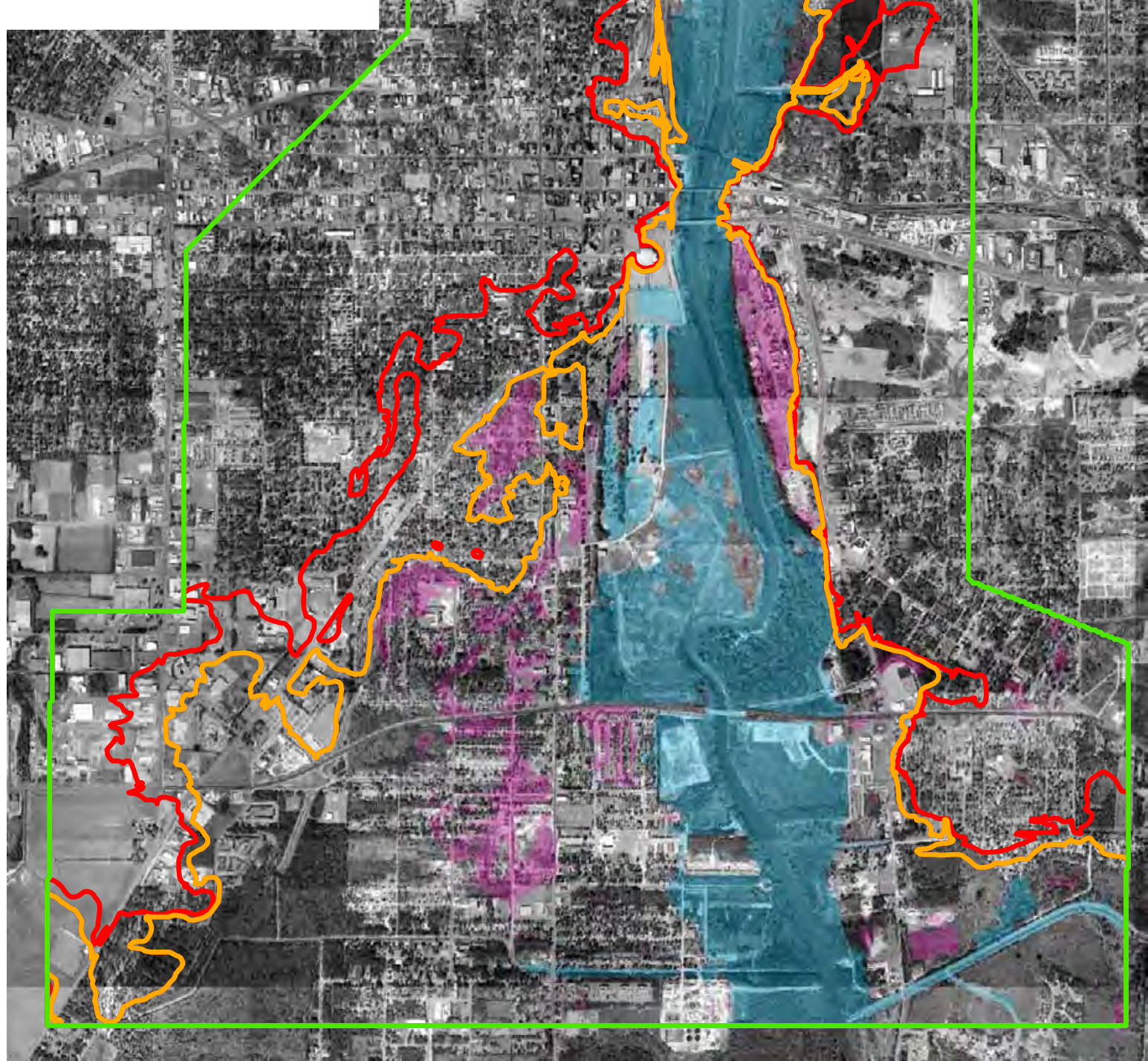

Image from Albany-Dougherty Planning Commission, 1996

Figure A5. Simulated flood inundation for a water-surface altitude of 183.5 feet at the Albany streamgage compared with Federal Emergency Management Agency's Digital Flood Insurance Rate Maps (DFIRM) for the Flint River in Albany, Georgia, 1998. 


\section{EXPLANATION}

\section{Modeled inundated areas}

Modeled low areas of possible inundation DFIRM 500-year floodplain DFIRM 100-year floodplain Study area

\section{- USGS streamgage}

Flood altitude at gage: 184.5 feet NAVD 88 Gage stage: 35 feet

Inflow: 75,400 cubic feet per second

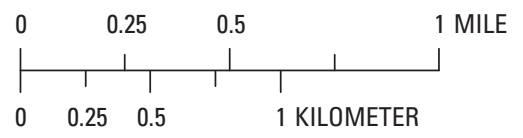

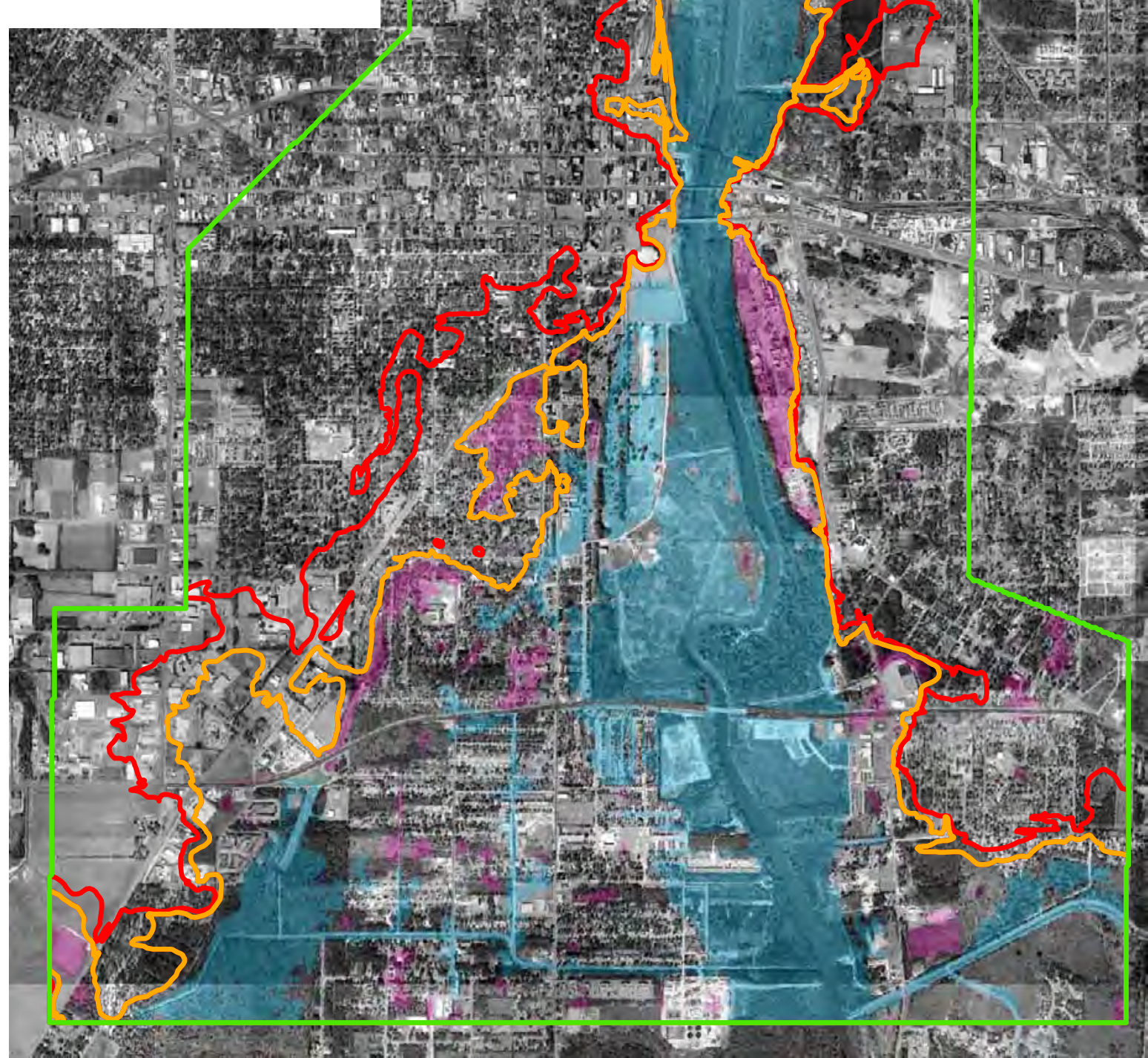

Image from Albany-Dougherty Planning Commission, 1996

Figure A6. Simulated flood inundation for a water-surface altitude of 184.5 feet at the Albany streamgage compared with Federal Emergency Management Agency's Digital Flood Insurance Rate Maps (DFIRM) for the Flint River in Albany, Georgia, 1998. 


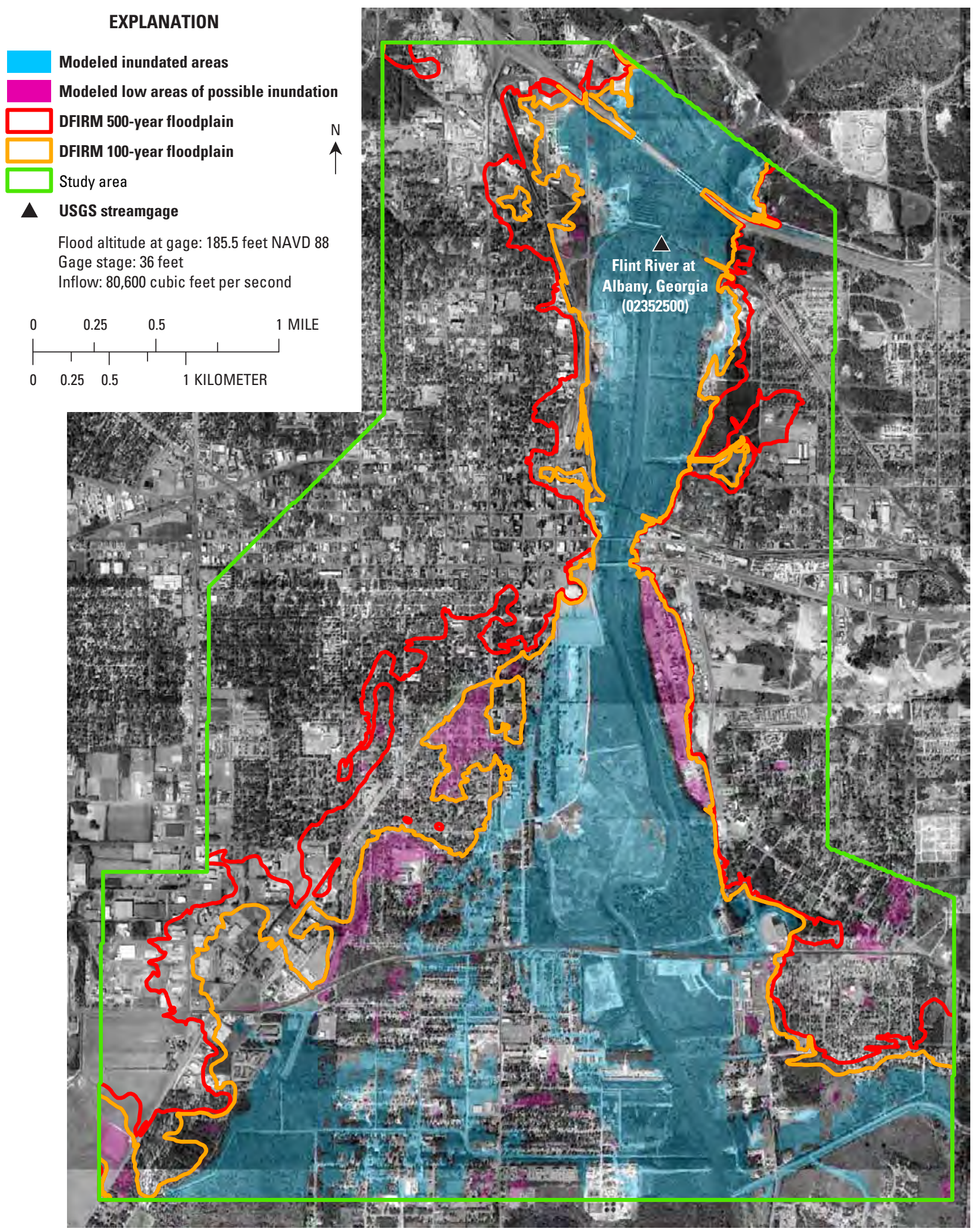

Image from Albany-Dougherty Planning Commission, 1996

Figure A7. Simulated flood inundation for a water-surface altitude of 185.5 feet at the Albany streamgage compared with Federal Emergency Management Agency's Digital Flood Insurance Rate Maps (DFIRM) for the Flint River in Albany, Georgia, 1998. 


\section{EXPLANATION}

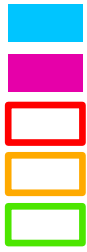

Modeled inundated areas

Modeled low areas of possible inundation DFIRM 500-year floodplain DFIRM 100-year floodplain Study area

- USGS streamgage

Flood altitude at gage: 186.5 feet NAVD 88 Gage stage: 37 feet

Inflow: 86,100 cubic feet per second

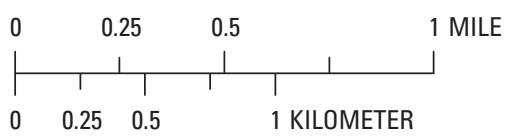

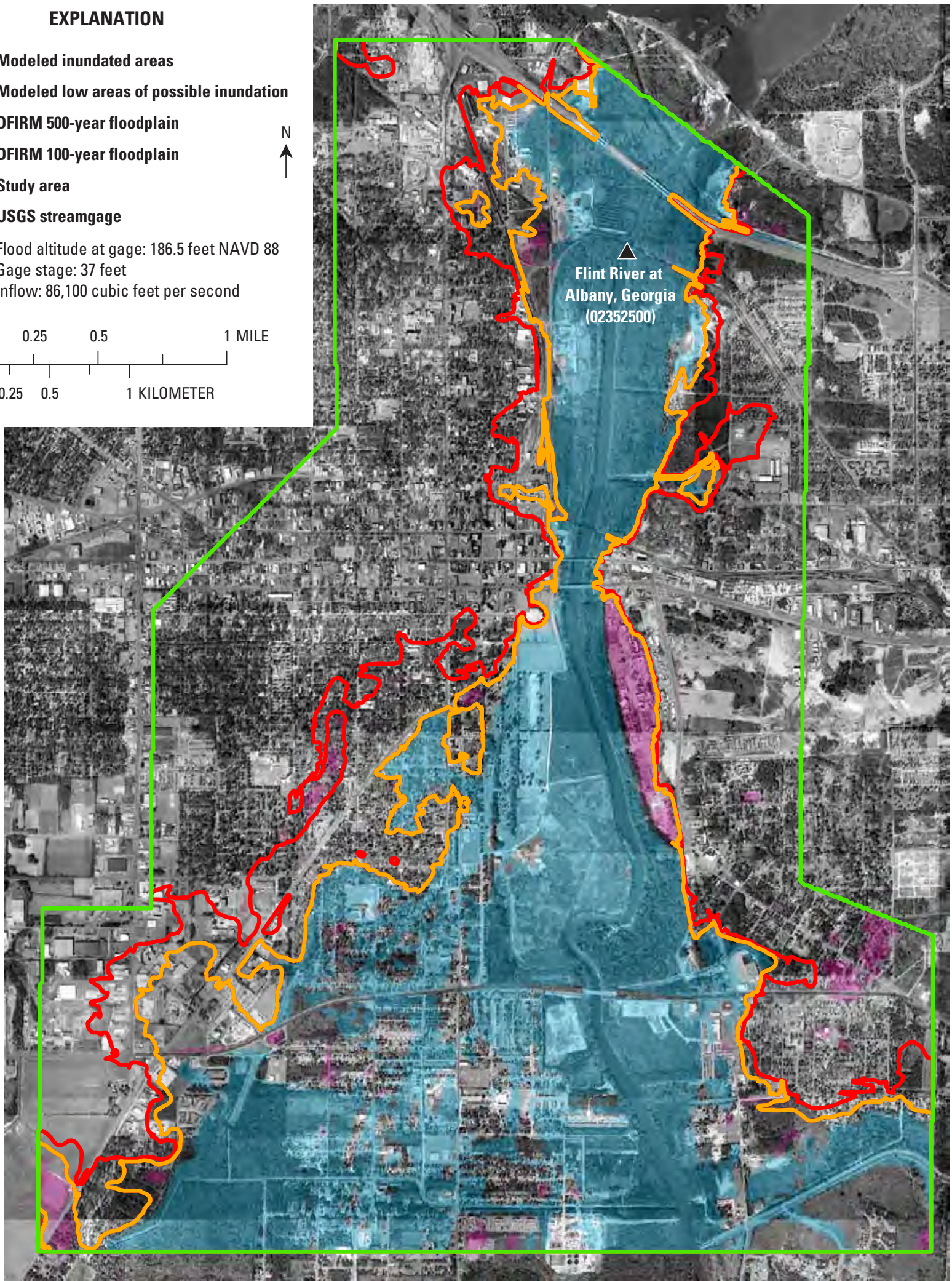

Image from Albany-Dougherty Planning Commission, 1996

Figure A8. Simulated flood inundation for a water-surface altitude of 186.5 feet at the Albany streamgage compared with Federal Emergency Management Agency's Digital Flood Insurance Rate Maps (DFIRM) for the Flint River in Albany, Georgia, 1998. 


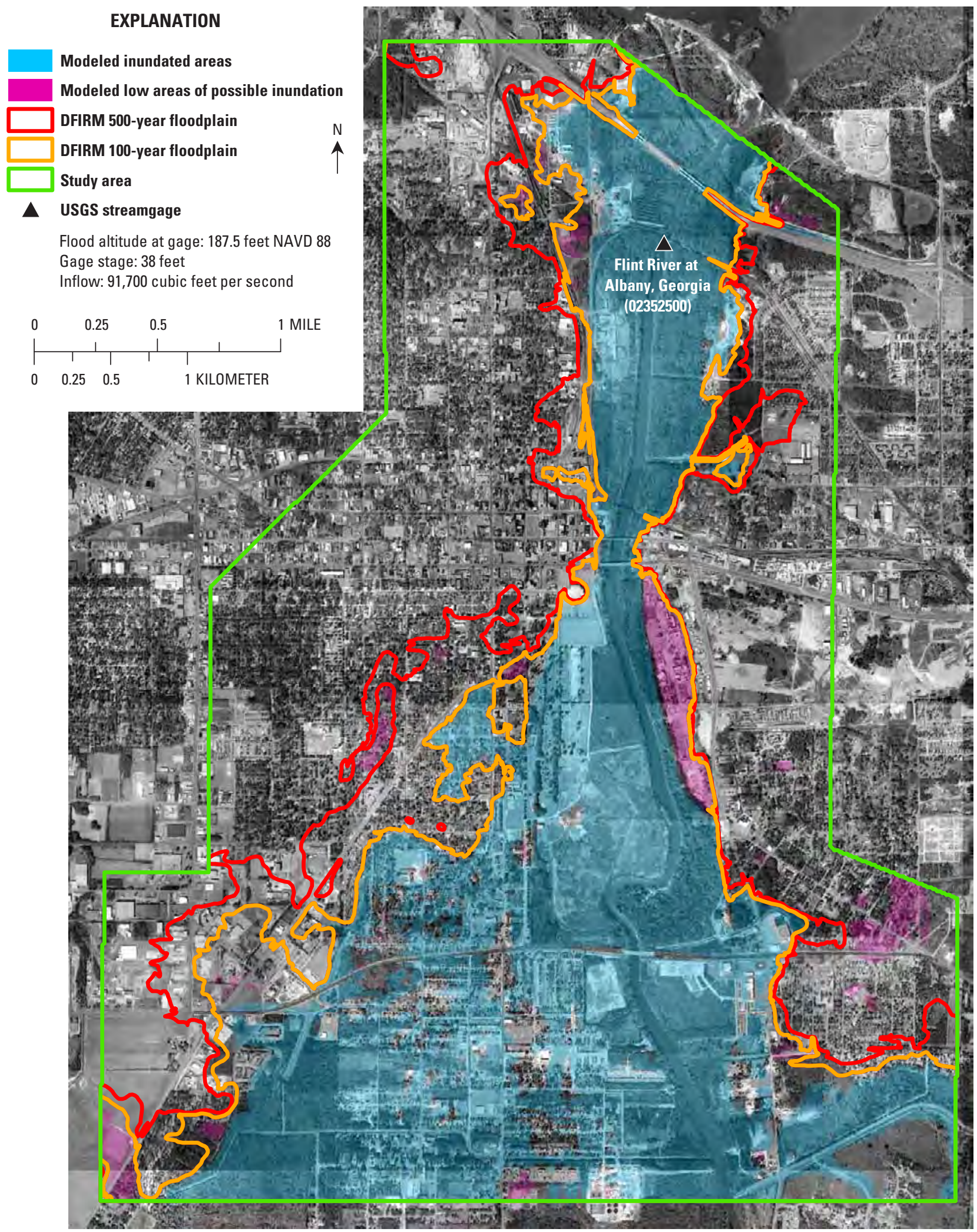

Image from Albany-Dougherty Planning Commission, 1996

Figure A9. Simulated flood inundation for a water-surface altitude of 187.5 feet at the Albany streamgage compared with Federal Emergency Management Agency's Digital Flood Insurance Rate Maps (DFIRM) for the Flint River in Albany, Georgia, 1998. 


\section{EXPLANATION}

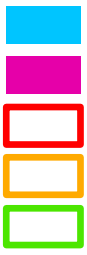

Modeled inundated areas

Modeled low areas of possible inundation DFIRM 500-year floodplain DFIRM 100-year floodplain Study area

$\Delta$ USGS streamgage

Flood altitude at gage: 188.5 feet NAVD 88 Gage stage: 39 feet

Inflow: 97,500 cubic feet per second

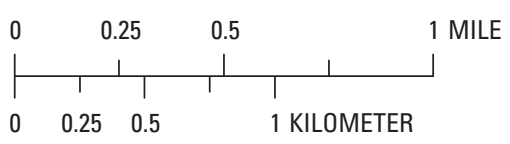

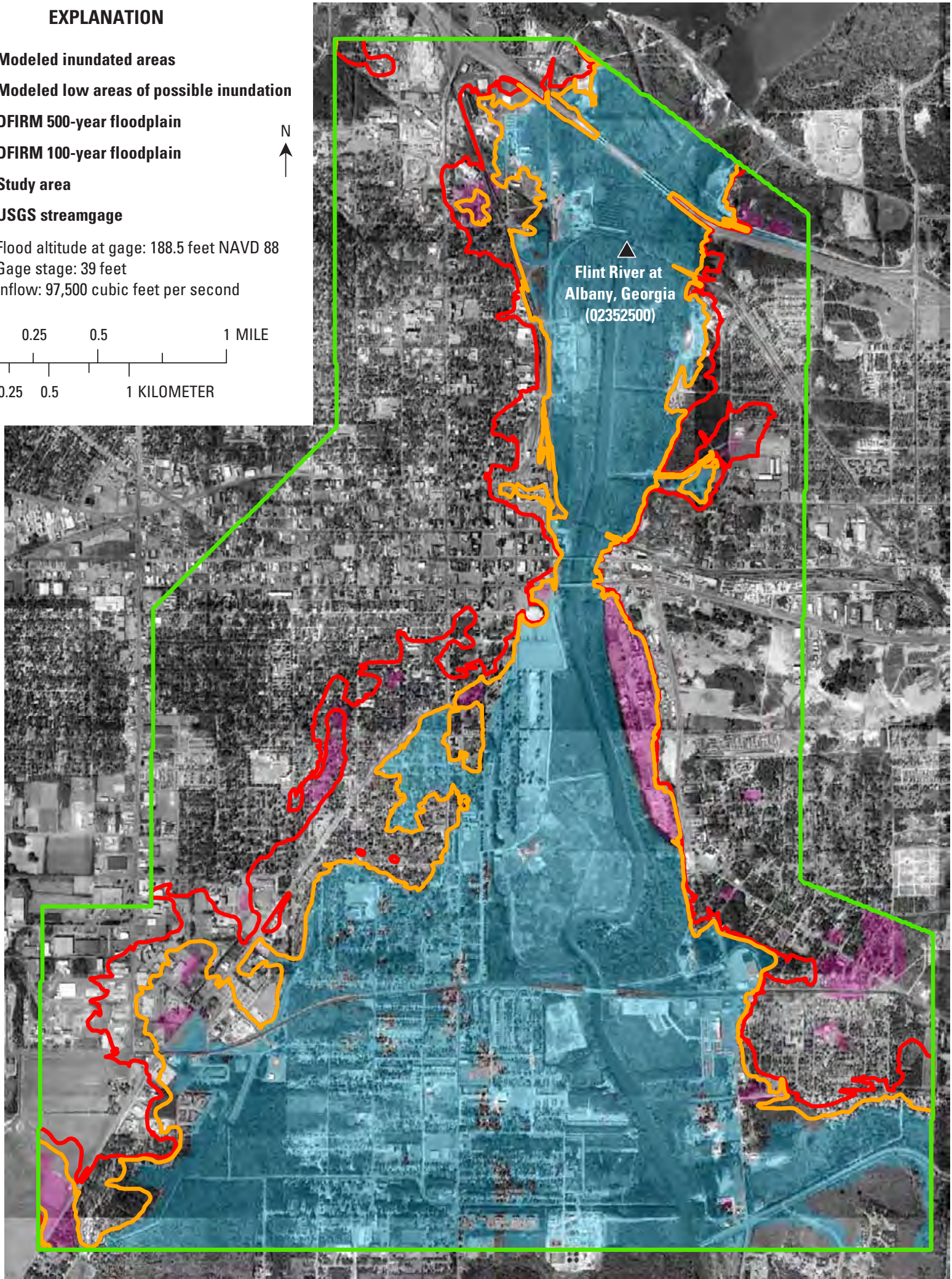

Image from Albany-Dougherty Planning Commission, 1996

Figure A10. Simulated flood inundation for a water-surface altitude of 188.5 feet at the Albany streamgage compared with Federal Emergency Management Agency's Digital Flood Insurance Rate Maps (DFIRM) for the Flint River in Albany, Georgia, 1998. 


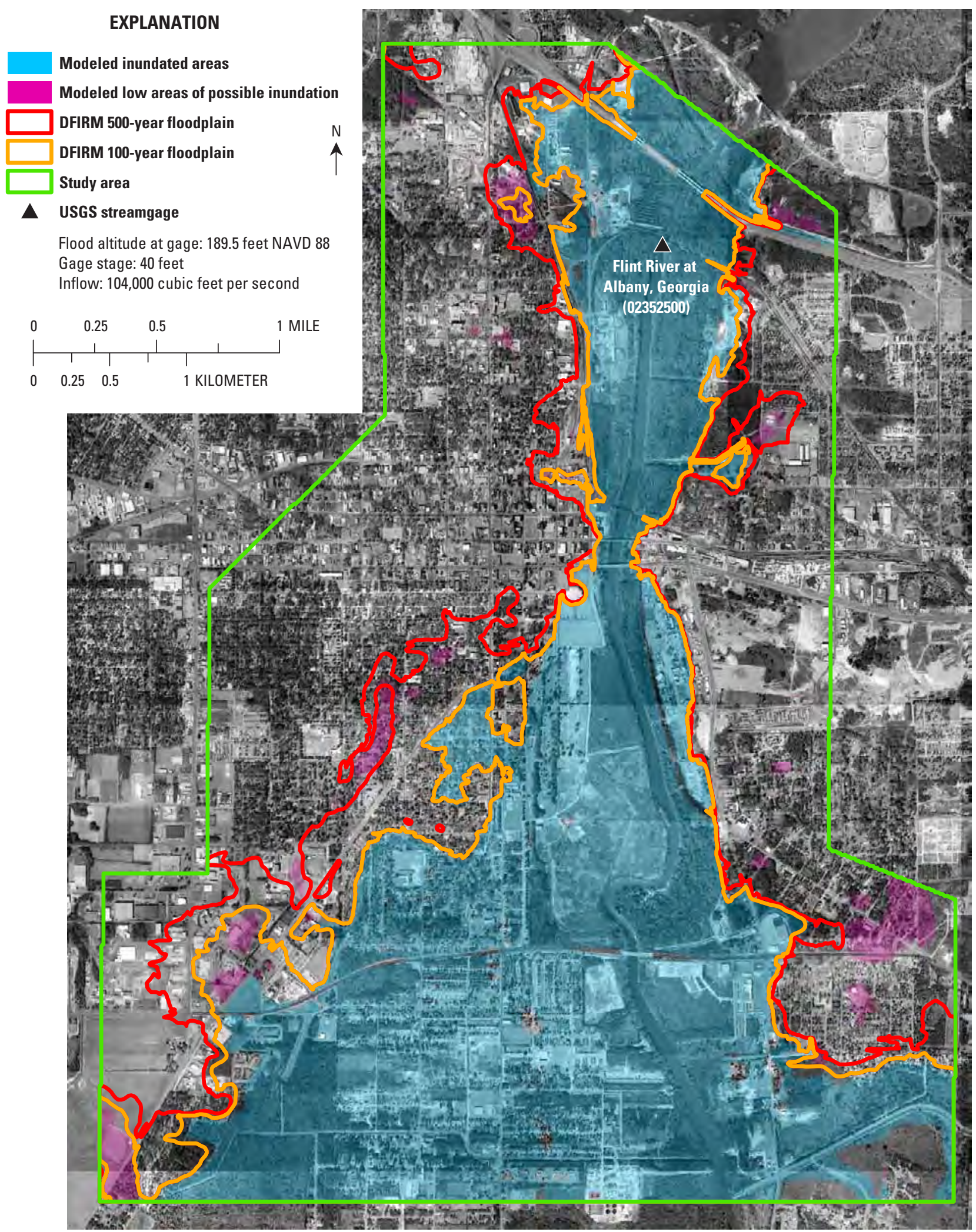

Image from Albany-Dougherty Planning Commission, 1996

Figure A11. Simulated flood inundation for a water-surface altitude of 189.5 feet at the Albany streamgage compared with Federal Emergency Management Agency's Digital Flood Insurance Rate Maps (DFIRM) for the Flint River in Albany, Georgia, 1998. 


\section{EXPLANATION}

\section{Modeled inundated areas}

Modeled low areas of possible inundation DFIRM 500-year floodplain DFIRM 100-year floodplain Study area

A USGS streamgage

Flood altitude at gage: 190.5 feet NAVD 88 Gage stage: 41 feet

Inflow: 110,000 cubic feet per second

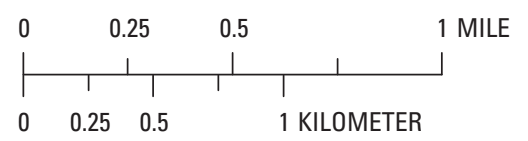

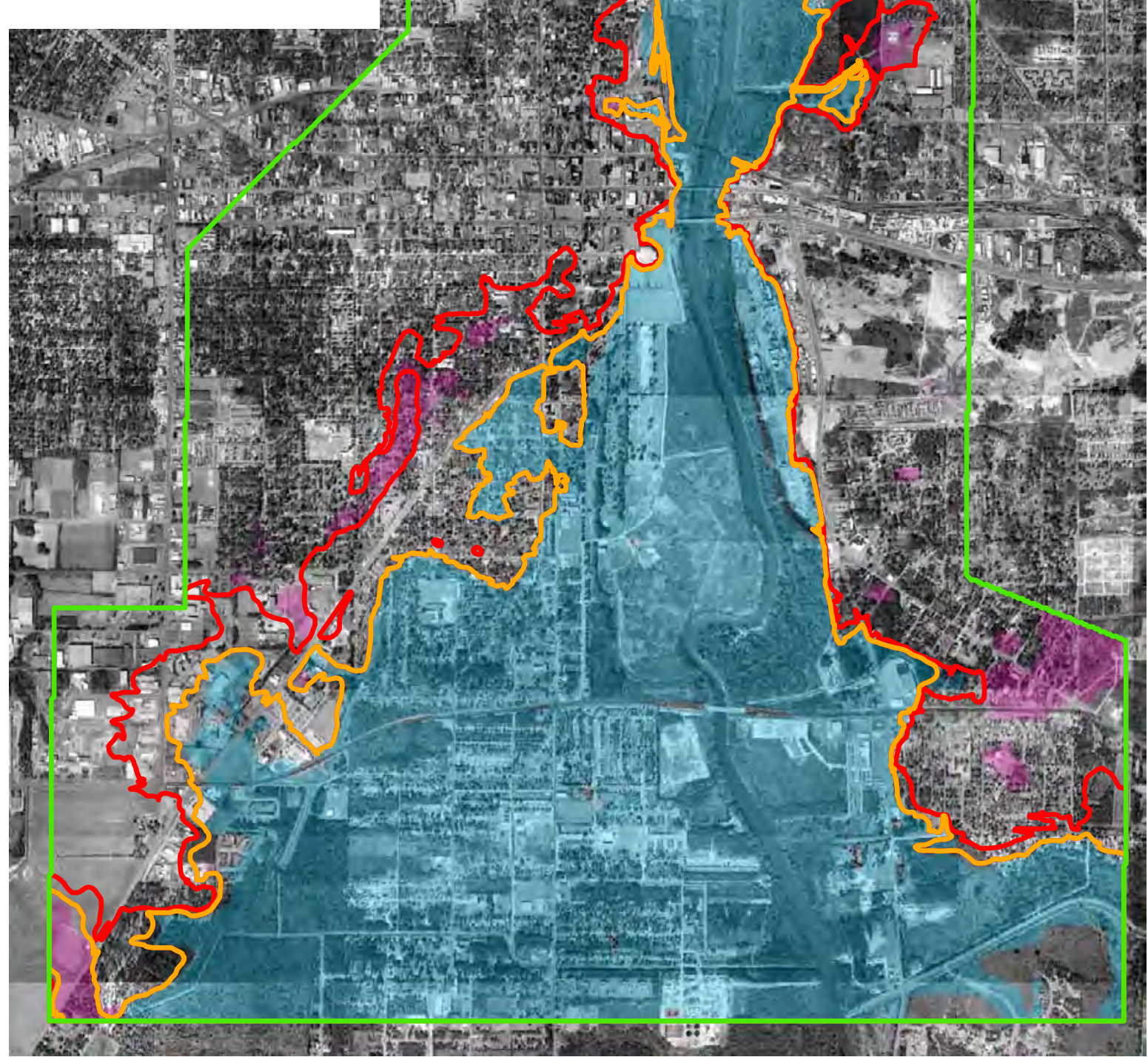

Image from Albany-Dougherty Planning Commission, 1996

Figure A12. Simulated flood inundation for a water-surface altitude of 190.5 feet at the Albany streamgage compared with Federal Emergency Management Agency's Digital Flood Insurance Rate Maps (DFIRM) for the Flint River in Albany, Georgia, 1998. 


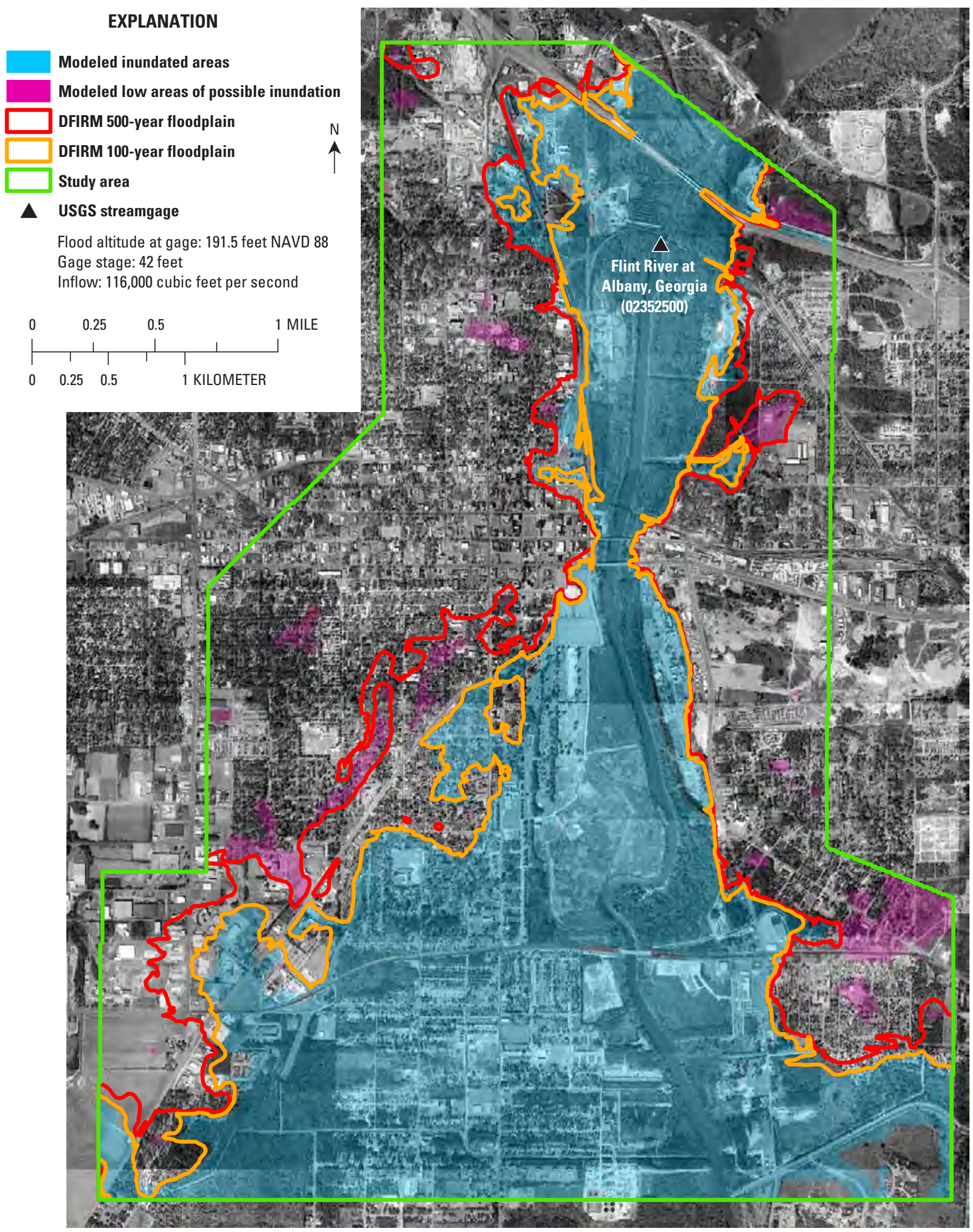

Image from Albany-Dougherty Planning Commission, 1996

Figure A13. Simulated flood inundation for a water-surface altitude of 191.5 feet at the Albany streamgage compared with Federal Emergency Management Agency's Digital Flood Insurance Rate Maps (DFIRM) for the Flint River in Albany, Georgia, 1998. 


\section{EXPLANATION}

Modeled inundated areas

Modeled low areas of possible inundation DFIRM 500-year floodplain DFIRM 100-year floodplain Study area

- USGS streamgage

Flood altitude at gage: 192.5 feet NAVD 88 Gage stage: 43 feet

Inflow: 123,000 cubic feet per second

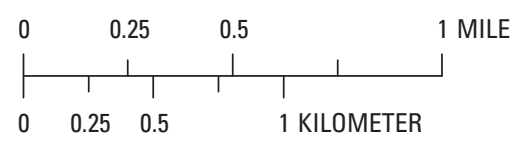

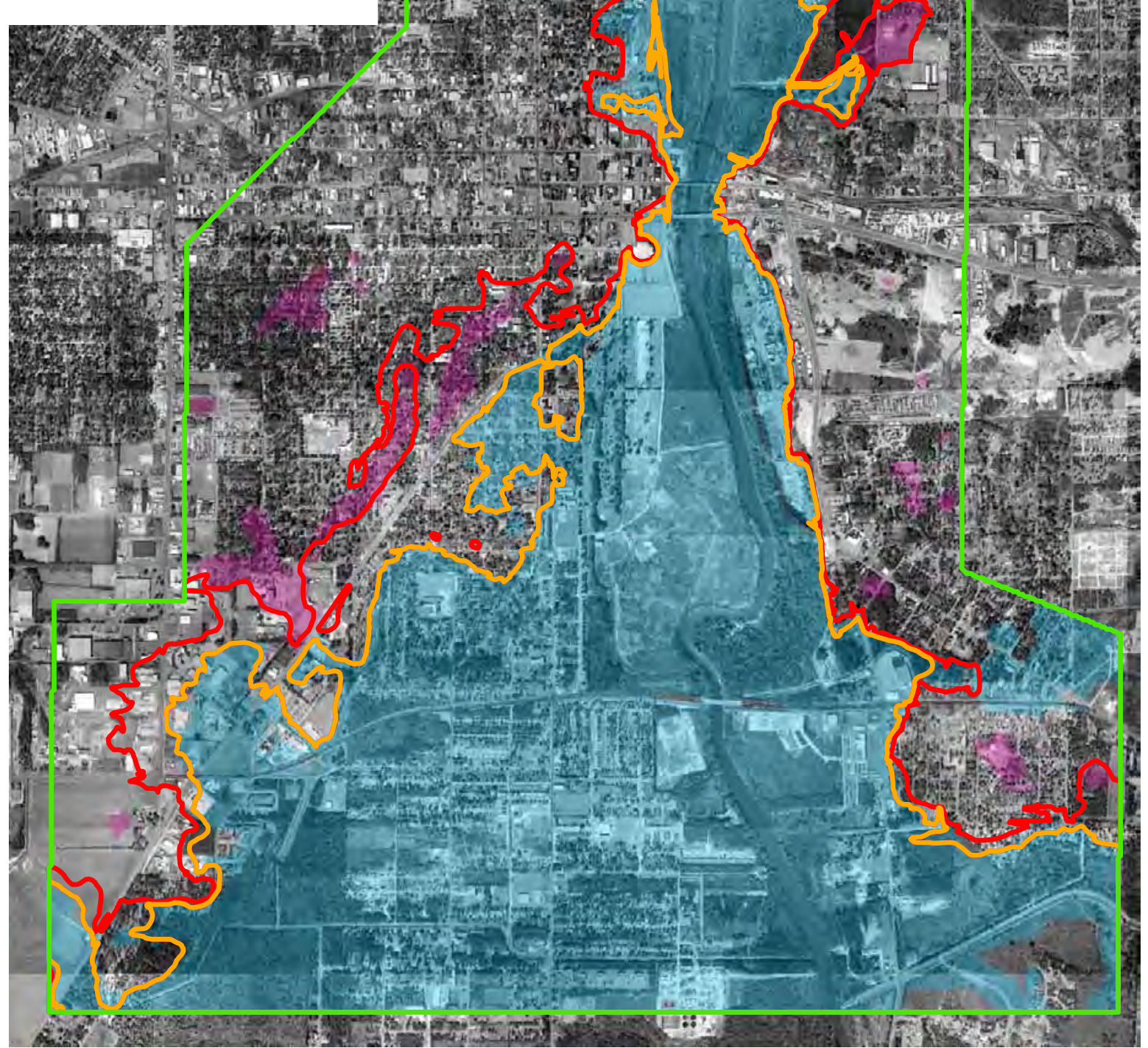

Image from Albany-Dougherty Planning Commission, 1996

Figure A14. Simulated flood inundation for a water-surface altitude of 192.5 feet at the Albany streamgage compared with Federal Emergency Management Agency's Digital Flood Insurance Rate Maps (DFIRM) for the Flint River in Albany, Georgia, 1998. 


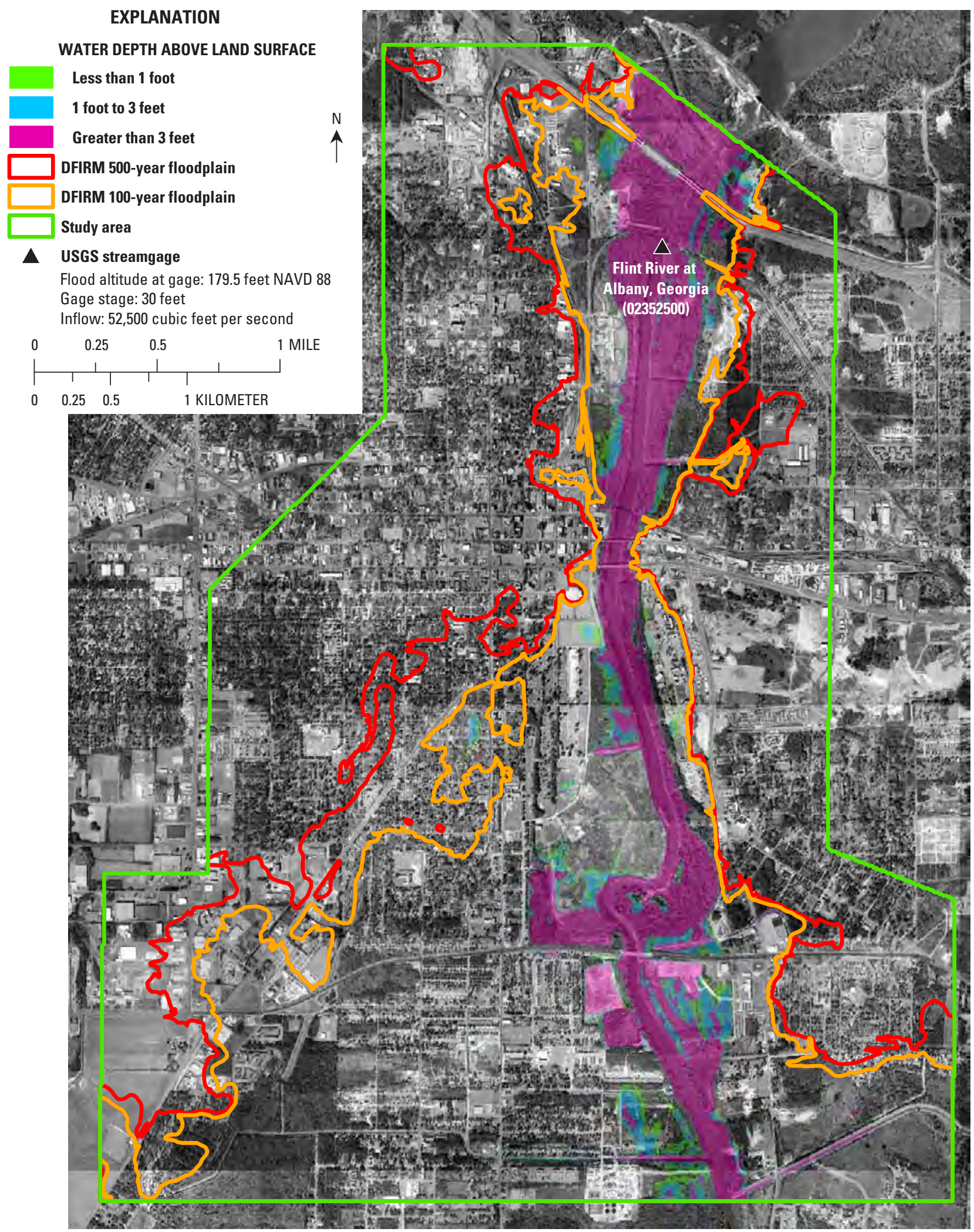

Image from Albany-Dougherty Planning Commission, 1996

Figure A15. Simulated flood-inundation hazard scale for a water-surface altitude of 179.5 feet at the Albany streamgage compared with Federal Emergency Management Agency's Digital Flood Insurance Rate Maps (DFIRM) for the Flint River in Albany, Georgia, 1998. 


\section{EXPLANATION}

\section{WATER DEPTH ABOVE LAND SURFACE}

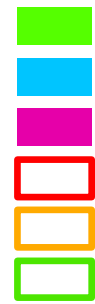

Less than 1 foot

1 foot to 3 feet

Greater than 3 feet

DFIRM 500-year floodplain

DFIRM 100-year floodplain

Study area

- USGS streamgage

Flood altitude at gage: 180.5 feet NAVD 88 Gage stage: 31 feet

Inflow: 56,700 cubic feet per second

$\begin{array}{lll}0.25 & 0.5 & 1 \mathrm{MIL}\end{array}$

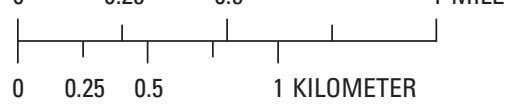
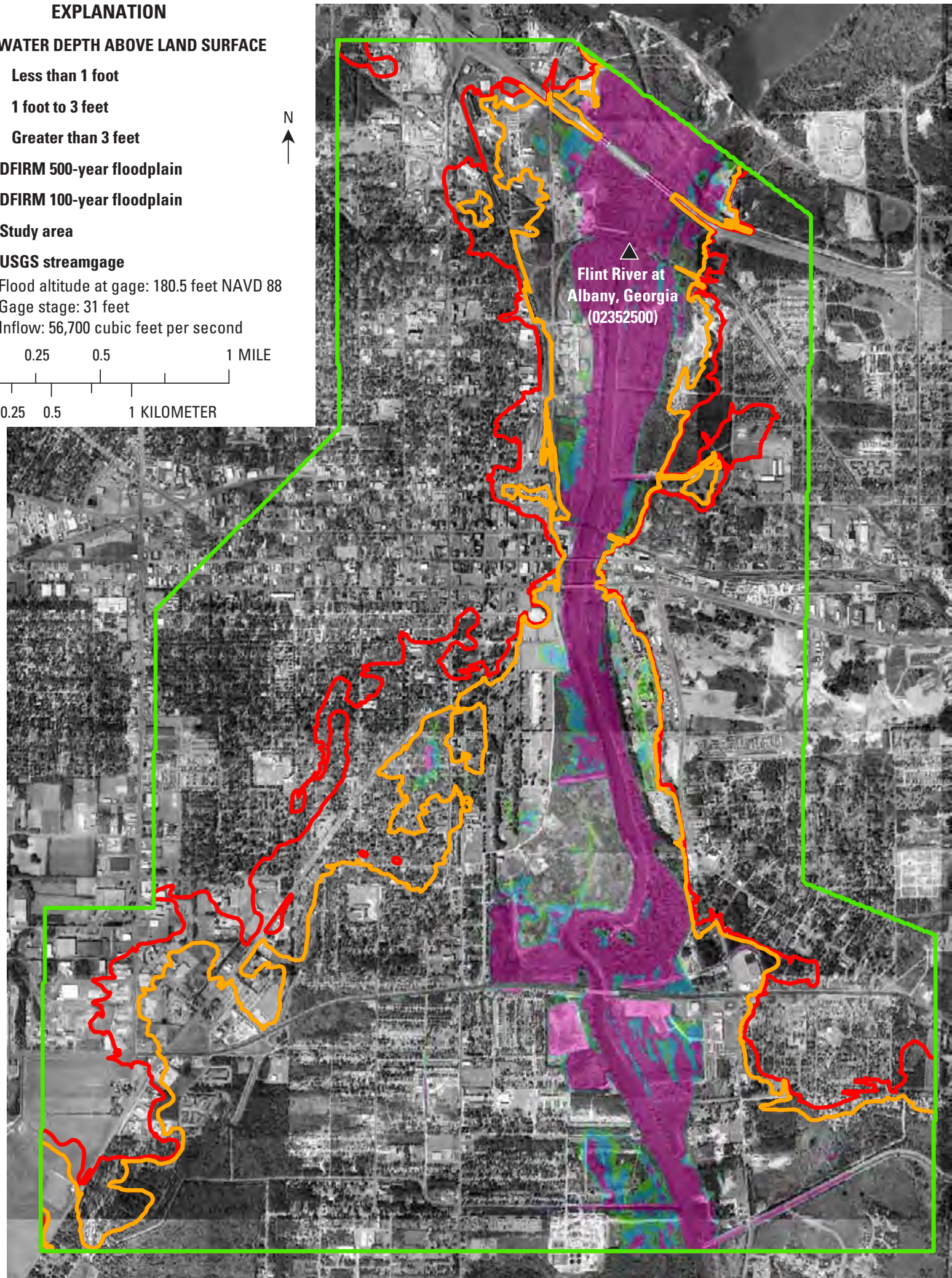

Image from Albany-Dougherty Planning Commission, 1996

Figure A16. Simulated flood-inundation hazard scale for a water-surface altitude of 180.5 feet at the Albany streamgage compared with Federal Emergency Management Agency's Digital Flood Insurance Rate Maps (DFIRM) for the Flint River in Albany, Georgia, 1998. 


\section{EXPLANATION}

WATER DEPTH ABOVE LAND SURFACE

Less than 1 foot

1 foot to 3 feet

Greater than 3 feet

DFIRM 500-year floodplain

DFIRM 100-year floodplain

Study area

- USGS streamgage

Flood altitude at gage: 181.5 feet NAVD 88 Gage stage: 32 feet

Inflow: 61,100 cubic feet per second
$\mathrm{N}$
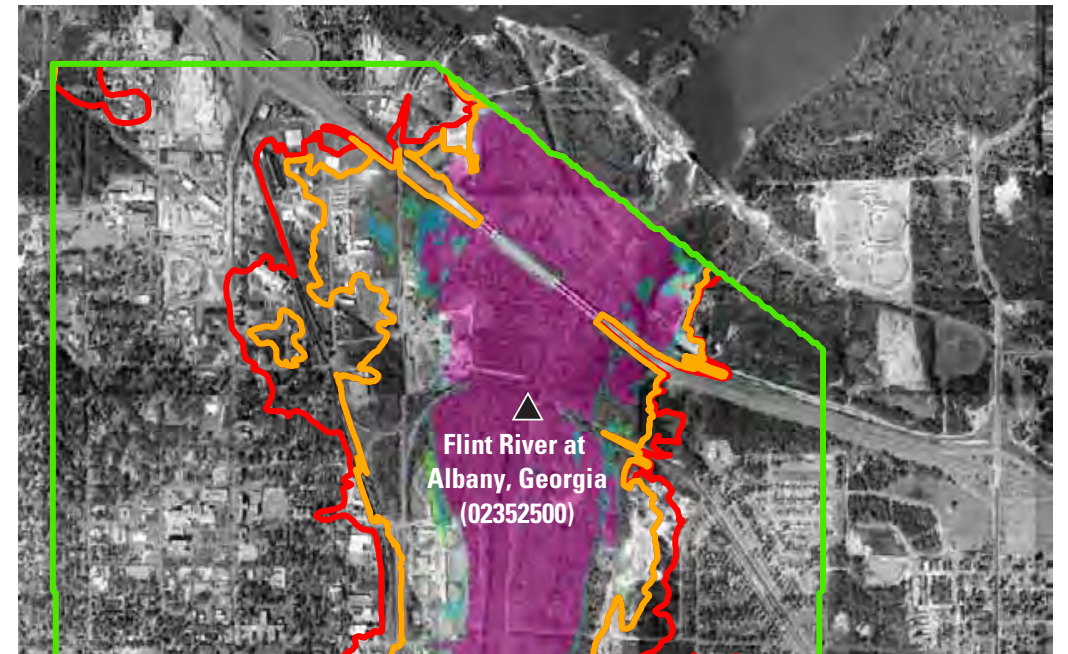

6
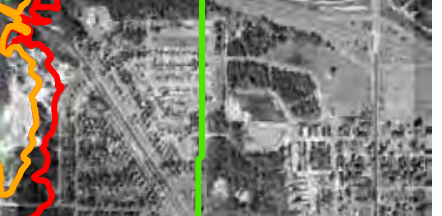

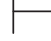

$\begin{array}{lll}0.25 & 0.5 & 1 \text { KILOMETER }\end{array}$
(P)

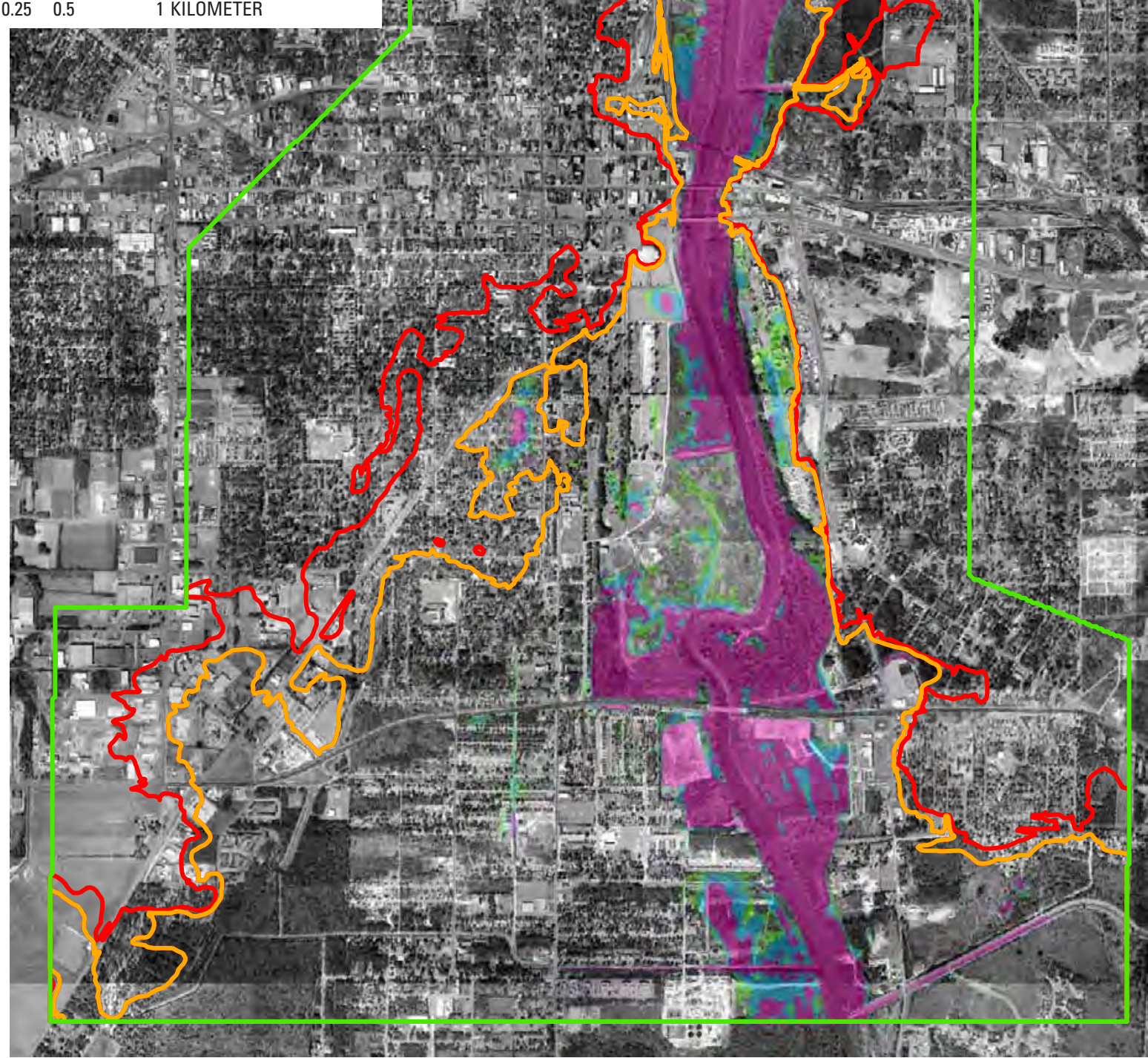

Image from Albany-Dougherty Planning Commission, 1996

Figure A17. Simulated flood-inundation hazard scale for a water-surface altitude of 181.5 feet at the Albany streamgage compared with Federal Emergency Management Agency's Digital Flood Insurance Rate Maps (DFIRM) for the Flint River in Albany, Georgia, 1998. 
EXPLANATION

\section{WATER DEPTH ABOVE LAND SURFACE}

Less than 1 foot

1 foot to 3 feet

Greater than 3 feet

DFIRM 500-year floodplain

DFIRM 100-year floodplain

Study area

- USGS streamgage

Flood altitude at gage: 182.5 feet NAVD 88 Gage stage: 33 feet

Inflow: 65,600 cubic feet per second

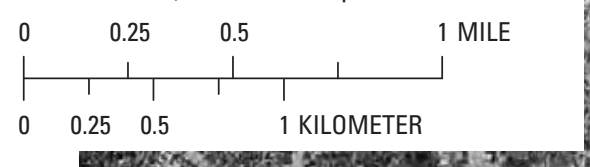

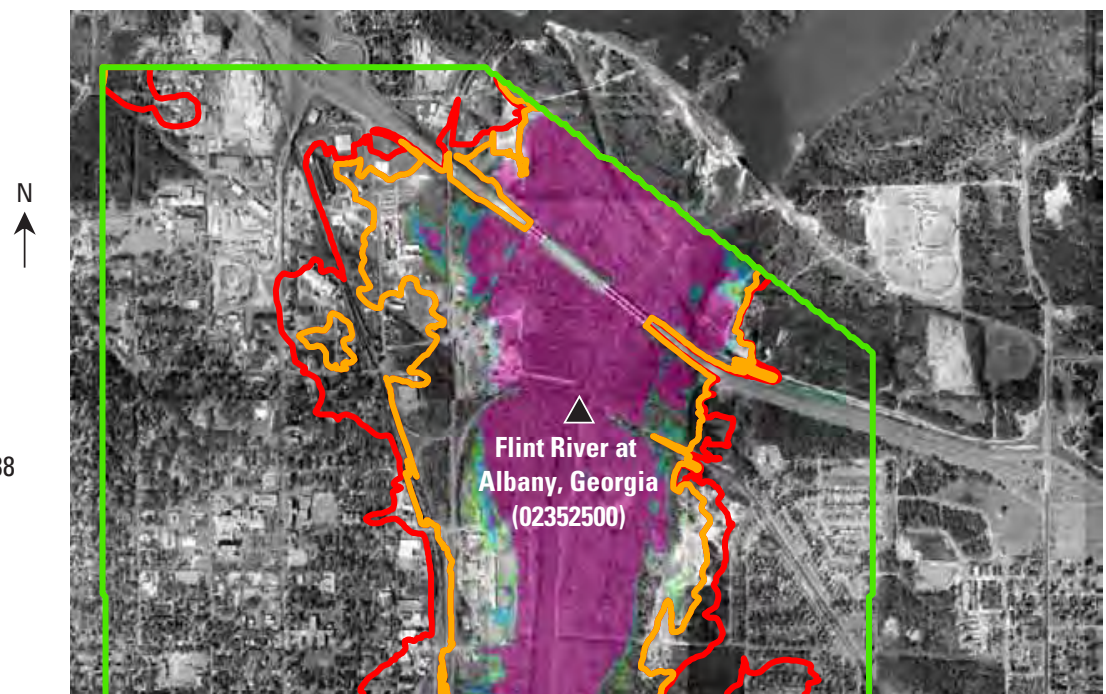

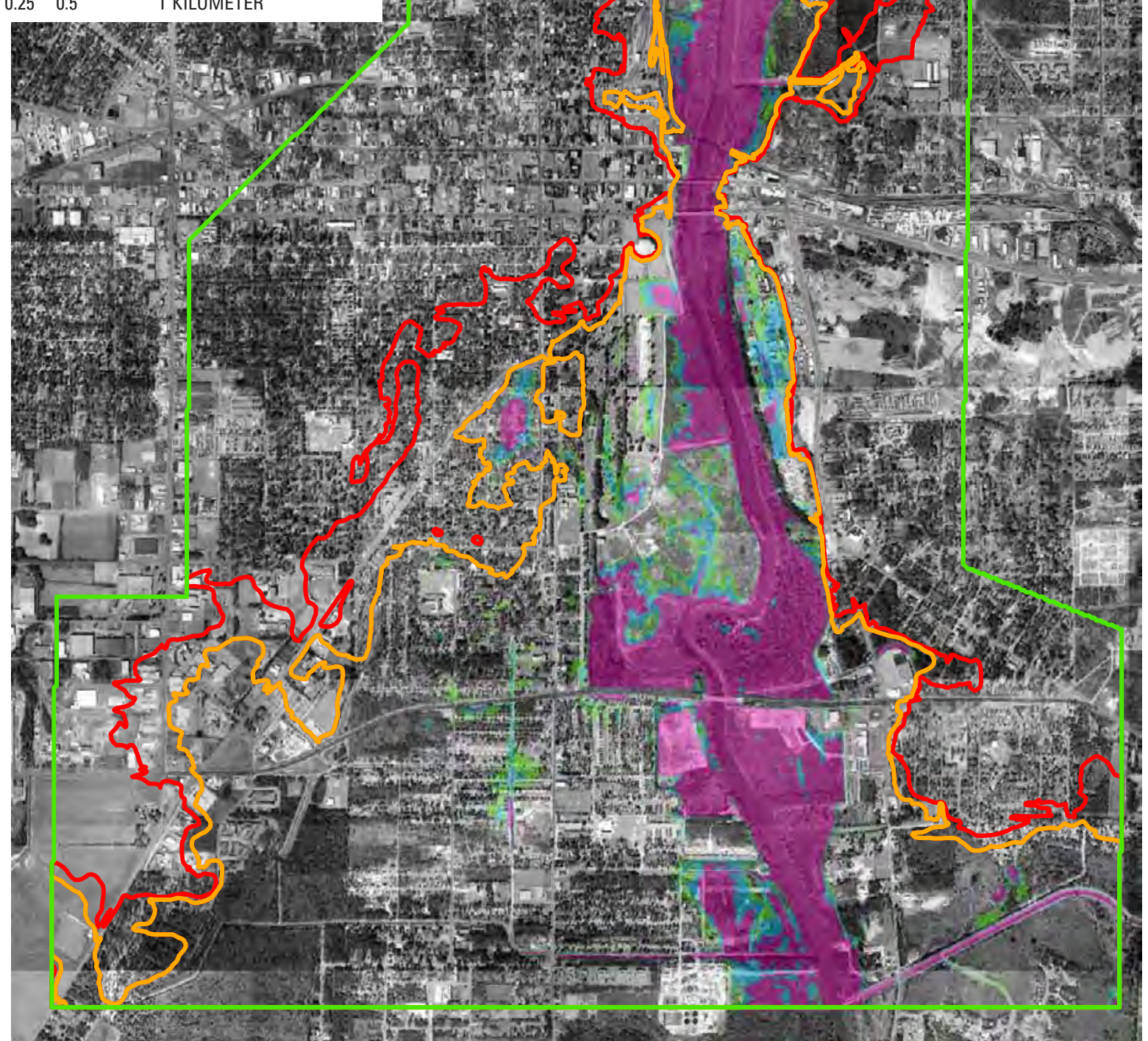

Image from Albany-Dougherty Planning Commission, 1996

Figure A18. Simulated flood-inundation hazard scale for a water-surface altitude of 182.5 feet at the Albany streamgage compared with Federal Emergency Management Agency's Digital Flood Insurance Rate Maps (DFIRM) for the Flint River in Albany, Georgia, 1998. 


\section{EXPLANATION}

WATER DEPTH ABOVE LAND SURFACE

\author{
Less than 1 foot
}

1 foot to 3 feet

Greater than 3 feet

DFIRM 500-year floodplain

DFIRM 100-year floodplain

Study area

A USGS streamgage

Flood altitude at gage: 183.5 feet NAVD 88 Gage stage: 34 feet

Inflow: 70,400 cubic feet per second

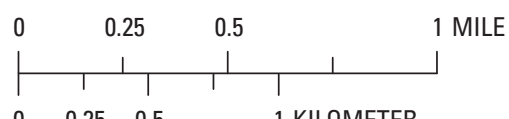

$\begin{array}{llll}0 & 0.25 & 0.5 & 1 \text { KILOMETER }\end{array}$

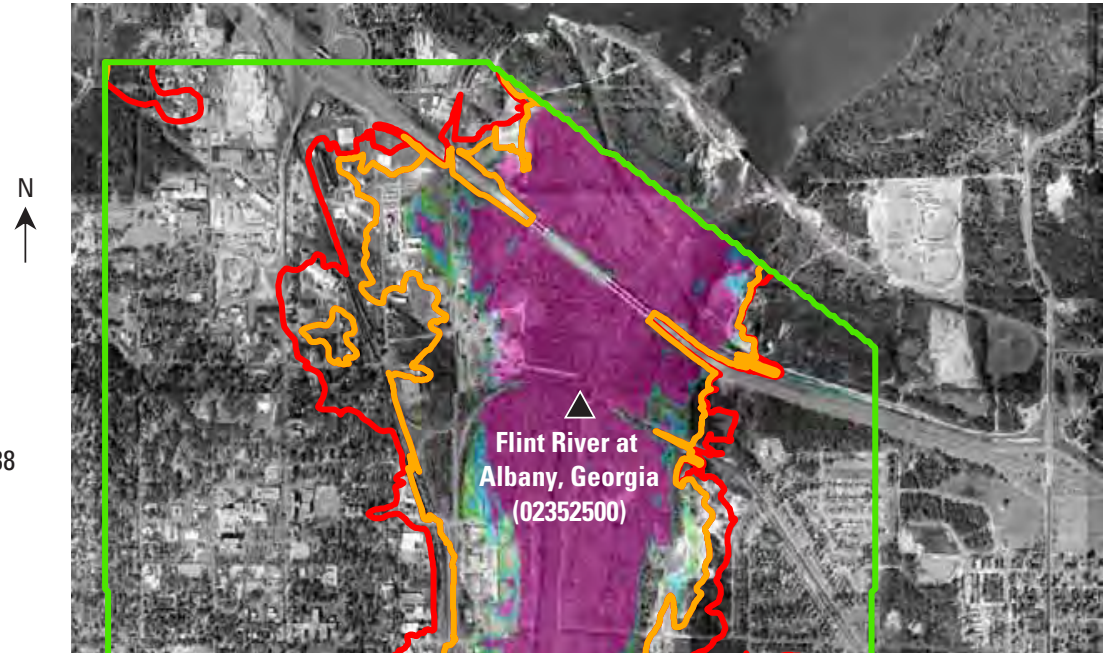
E.
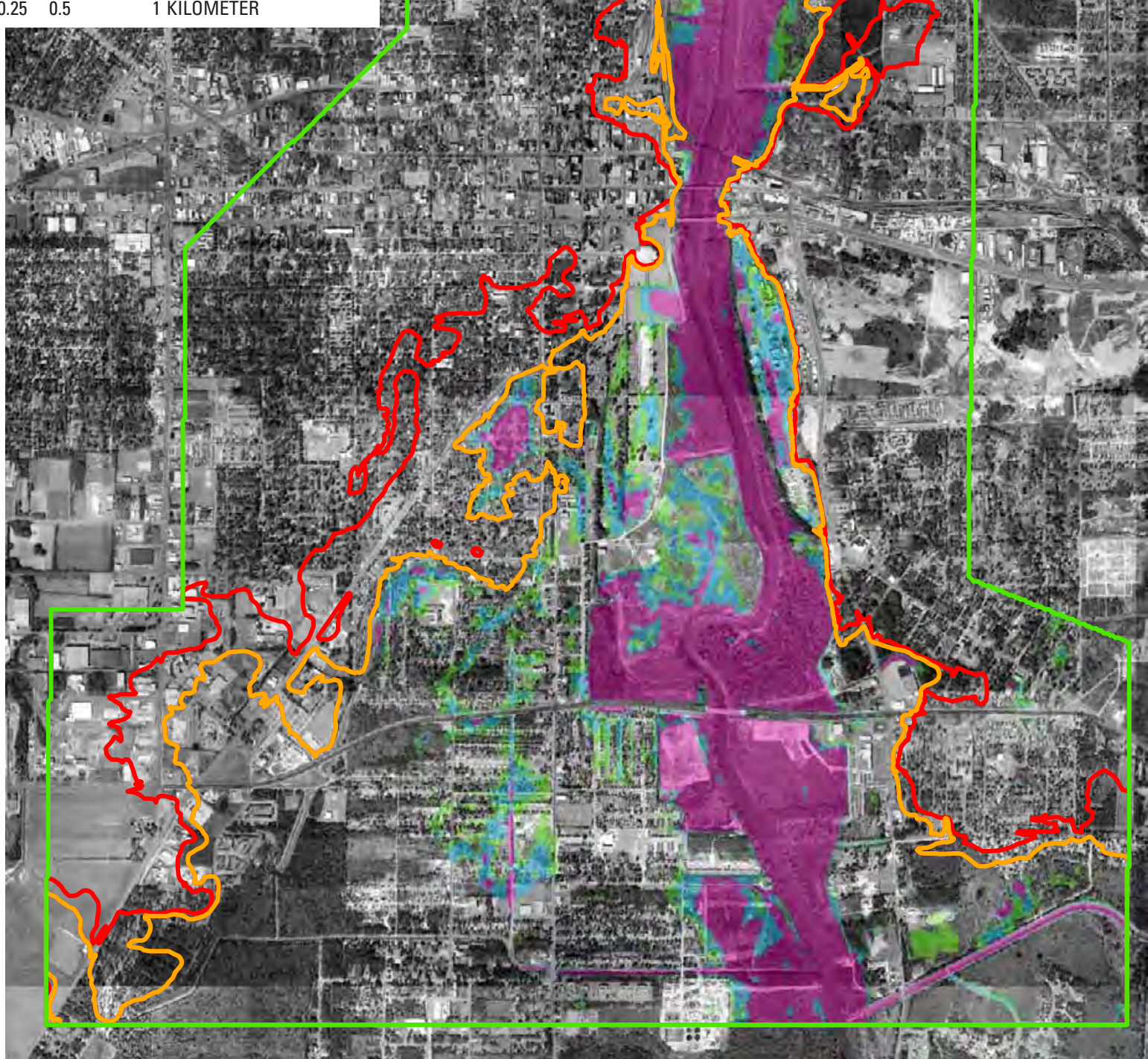

Image from Albany-Dougherty Planning Commission, 1996

Figure A19. Simulated flood-inundation hazard scale for a water-surface altitude of 183.5 feet at the Albany streamgage compared with Federal Emergency Management Agency's Digital Flood Insurance Rate Maps (DFIRM) for the Flint River in Albany, Georgia, 1998. 


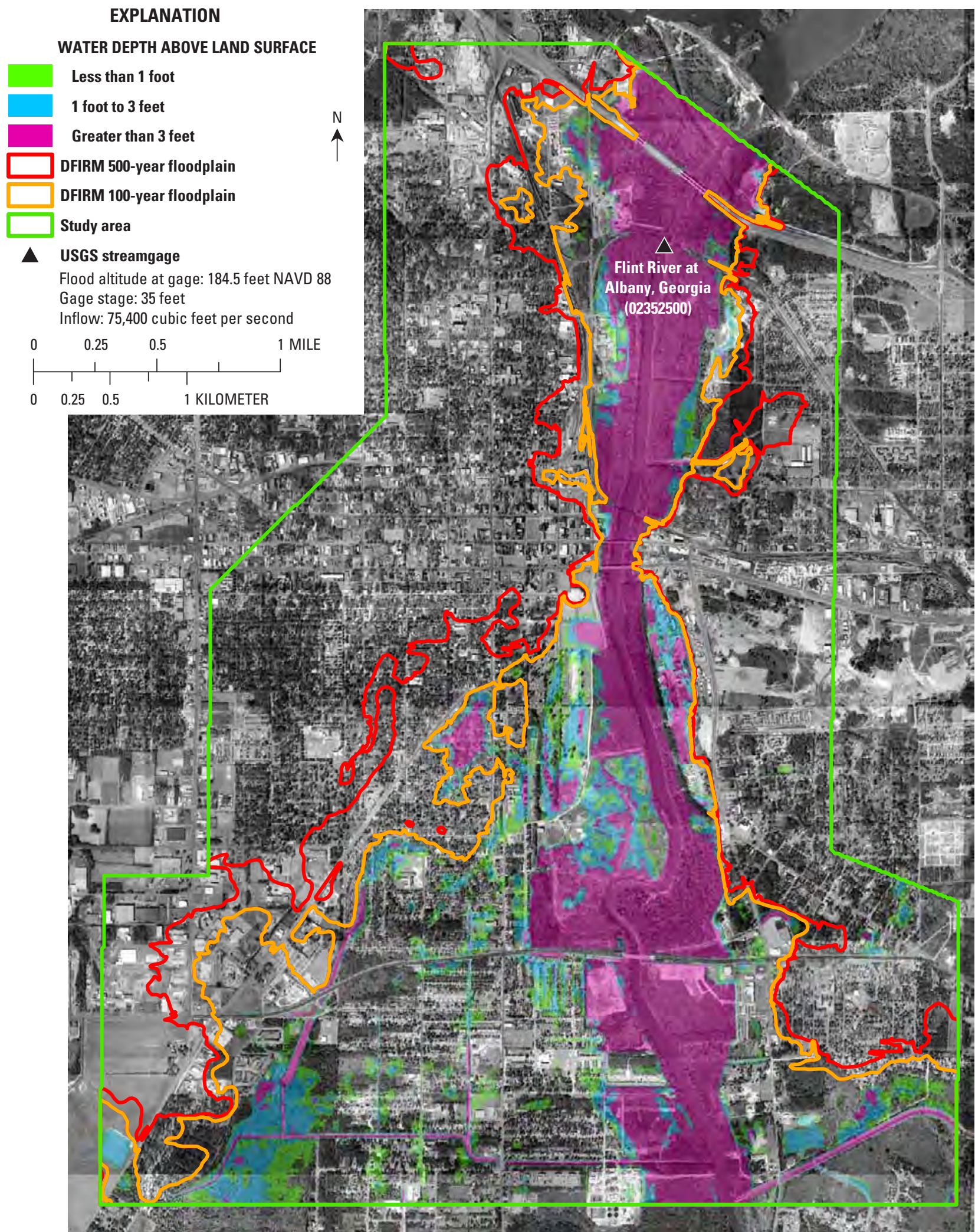

Image from Albany-Dougherty Planning Commission, 1996

Figure A20. Simulated flood-inundation hazard scale for a water-surface altitude of 184.5 feet at the Albany streamgage compared with Federal Emergency Management Agency's Digital Flood Insurance Rate Maps (DFIRM) for the Flint River in Albany, Georgia, 1998. 


\section{EXPLANATION}

WATER DEPTH ABOVE LAND SURFACE

Less than 1 foot

1 foot to 3 feet

Greater than 3 feet

DFIRM 500-year floodplain

DFIRM 100-year floodplain

Study area

- USGS streamgage

Flood altitude at gage: 185.5 feet NAVD 88 Gage stage: 36 feet

Inflow: 80,600 cubic feet per second

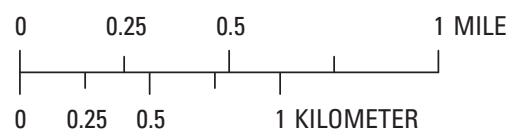

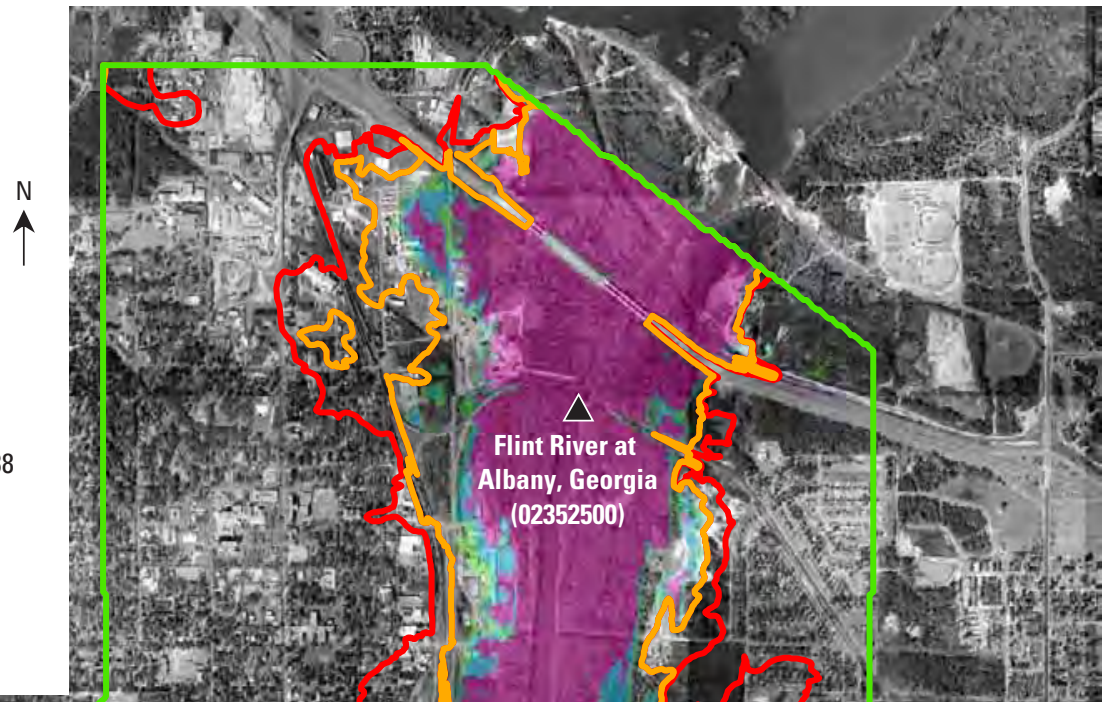
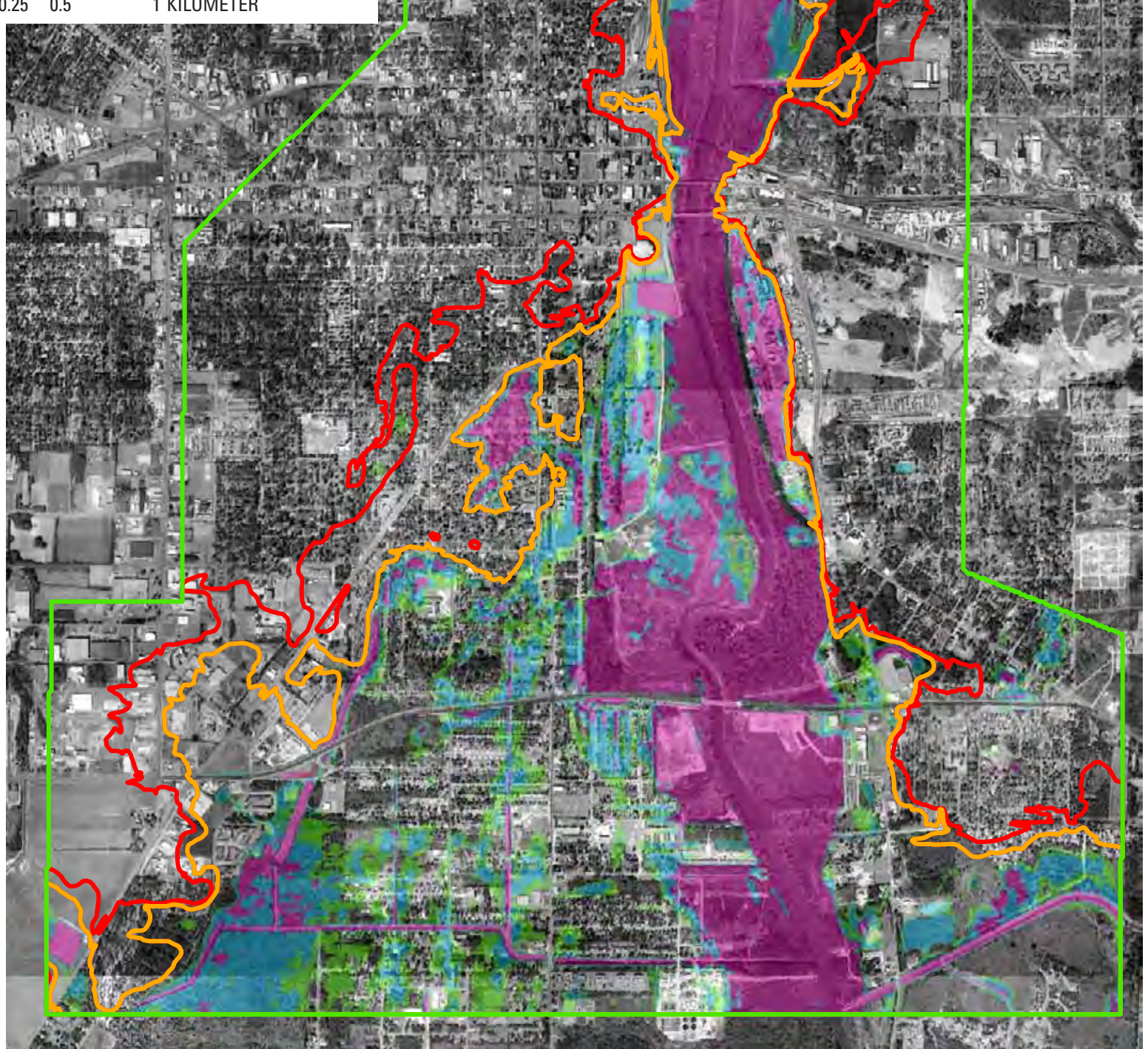

Image from Albany-Dougherty Planning Commission, 1996

Figure A21. Simulated flood-inundation hazard scale for a water-surface altitude of 185.5 feet at the Albany streamgage compared with Federal Emergency Management Agency's Digital Flood Insurance Rate Maps (DFIRM) for the Flint River in Albany, Georgia, 1998. 
EXPLANATION

WATER DEPTH ABOVE LAND SURFACE

Less than 1 foot

1 foot to 3 feet

Greater than 3 feet

DFIRM 500-year floodplain

DFIRM 100-year floodplain

Study area

- USGS streamgage

Flood altitude at gage: 186.5 feet NAVD 88 Gage stage: 37 feet

Inflow: 86,100 cubic feet per second

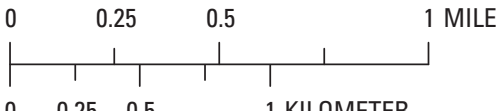

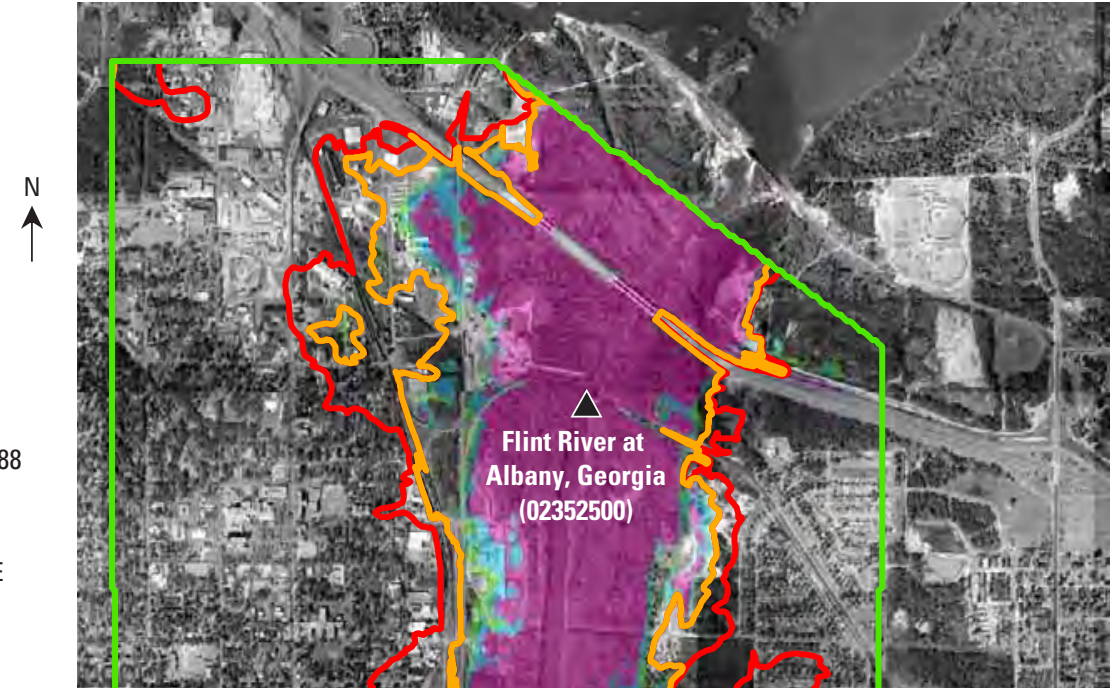

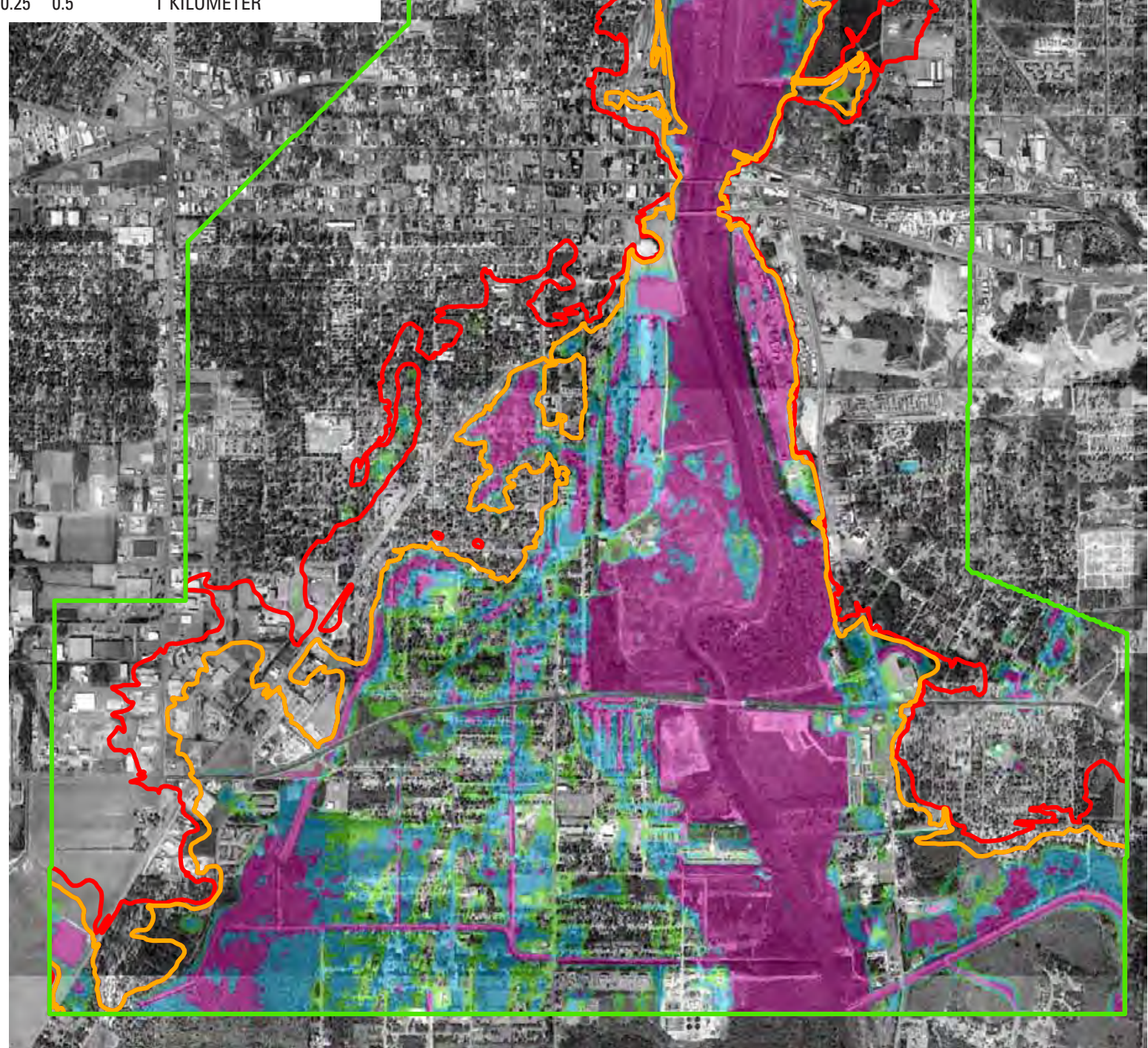

Image from Albany-Dougherty Planning Commission, 1996

Figure A22. Simulated flood-inundation hazard scale for a water-surface altitude of 186.5 feet at the Albany streamgage compared with Federal Emergency Management Agency's Digital Flood Insurance Rate Maps (DFIRM) for the Flint River in Albany, Georgia, 1998. 


\section{EXPLANATION}

WATER DEPTH ABOVE LAND SURFACE

Less than 1 foot

1 foot to 3 feet

Greater than 3 feet

DFIRM 500-year floodplain

DFIRM 100-year floodplain

Study area

A USGS streamgage

Flood altitude at gage: 187.5 feet NAVD 88 Gage stage: 38 feet

Inflow: 91,700 cubic feet per second

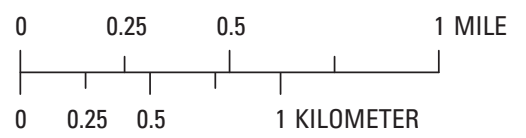
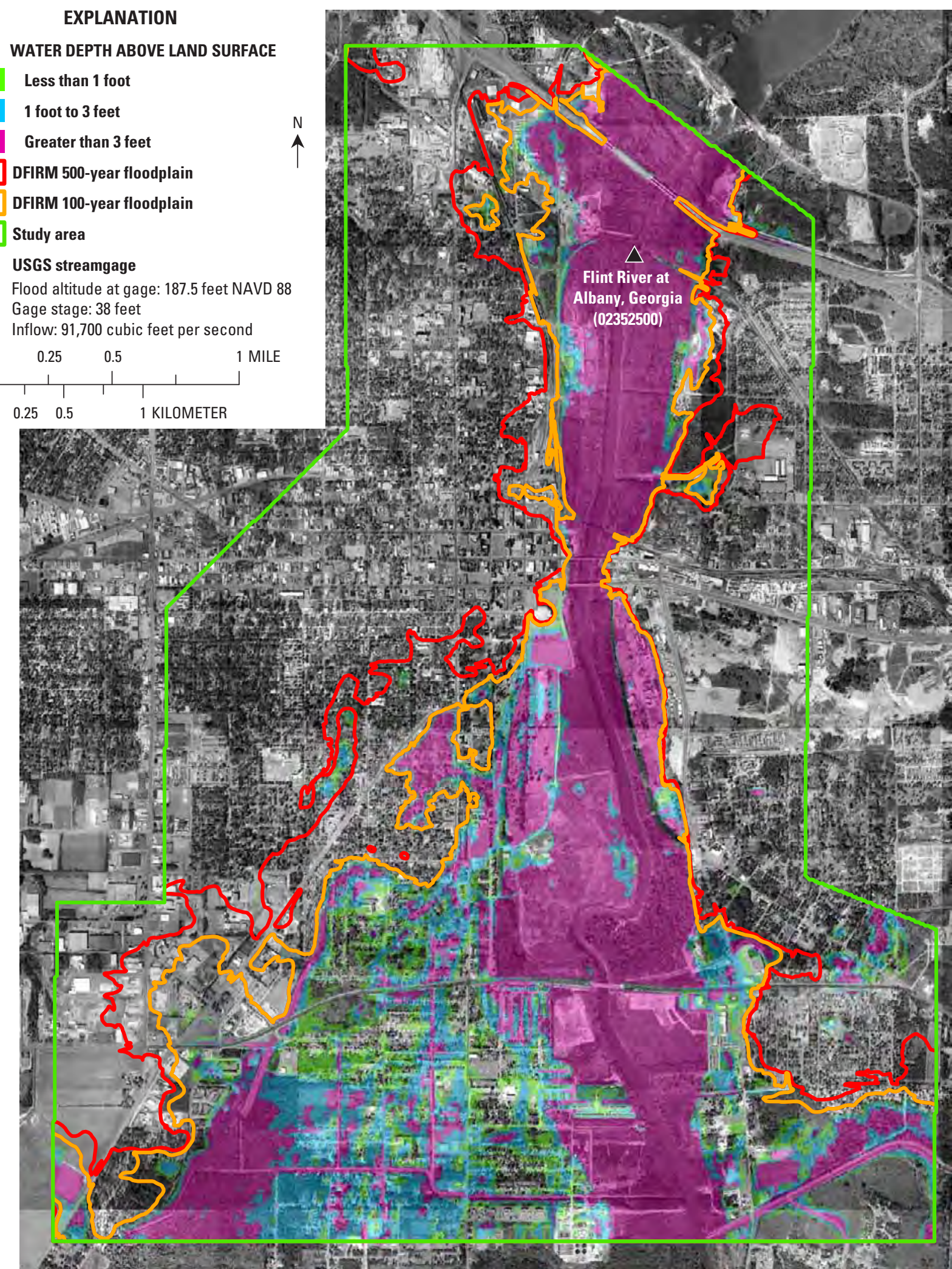

Image from Albany-Dougherty Planning Commission, 1996

Figure A23. Simulated flood-inundation hazard scale for a water-surface altitude of 187.5 feet at the Albany streamgage compared with Federal Emergency Management Agency's Digital Flood Insurance Rate Maps (DFIRM) for the Flint River in Albany, Georgia, 1998. 


\section{EXPLANATION}

\section{WATER DEPTH ABOVE LAND SURFACE}

\section{Less than 1 foot}

1 foot to 3 feet

Greater than 3 feet

DFIRM 500-year floodplain

DFIRM 100-year floodplain

\section{Study area}

- USGS streamgage

Flood altitude at gage: 188.5 feet NAVD 88 Gage stage: 39 feet

Inflow: 97,500 cubic feet per second

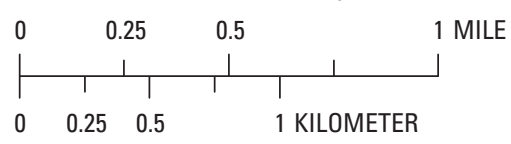

$\mathrm{N}$

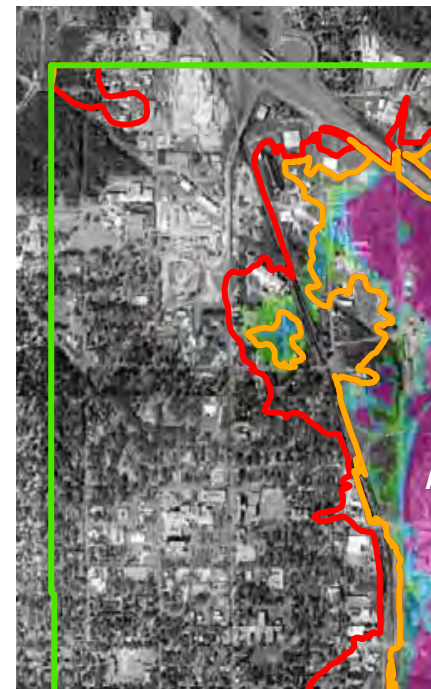

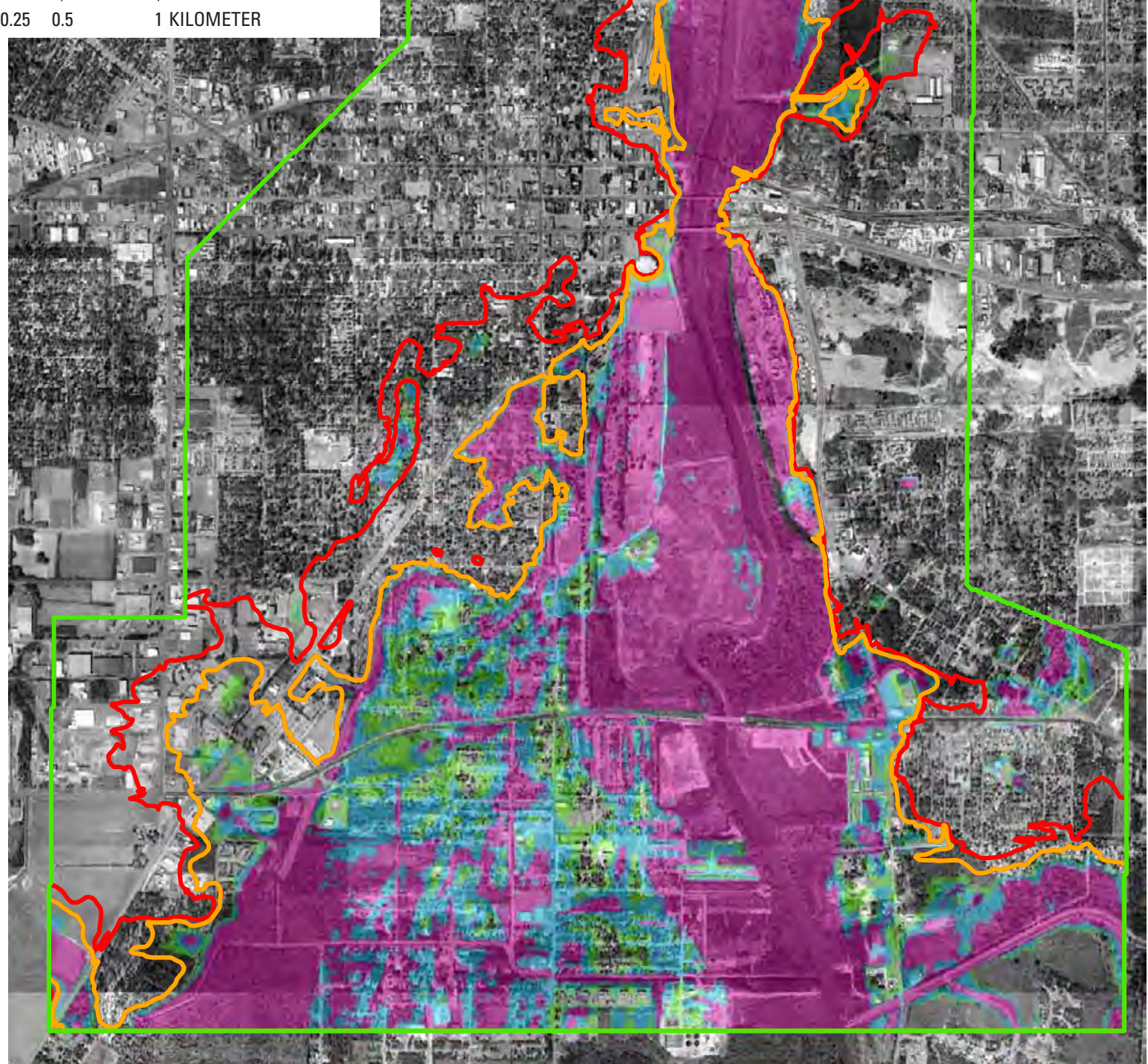

Image from Albany-Dougherty Planning Commission, 1996

Figure A24. Simulated flood-inundation hazard scale for a water-surface altitude of 188.5 feet at the Albany streamgage compared with Federal Emergency Management Agency's Digital Flood Insurance Rate Maps (DFIRM) for the Flint River in Albany, Georgia, 1998. 


\section{EXPLANATION}

WATER DEPTH ABOVE LAND SURFACE

\author{
Less than 1 foot
}

1 foot to 3 feet

Greater than 3 feet

DFIRM 500-year floodplain

DFIRM 100-year floodplain

Study area

- USGS streamgage

Flood altitude at gage: 189.5 feet NAVD 88 Gage stage: 40 feet

Inflow: 104,000 cubic feet per second

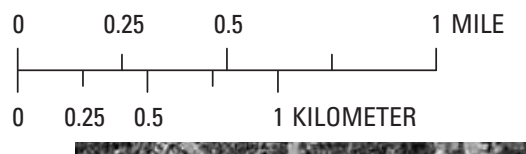

$\mathrm{N}$

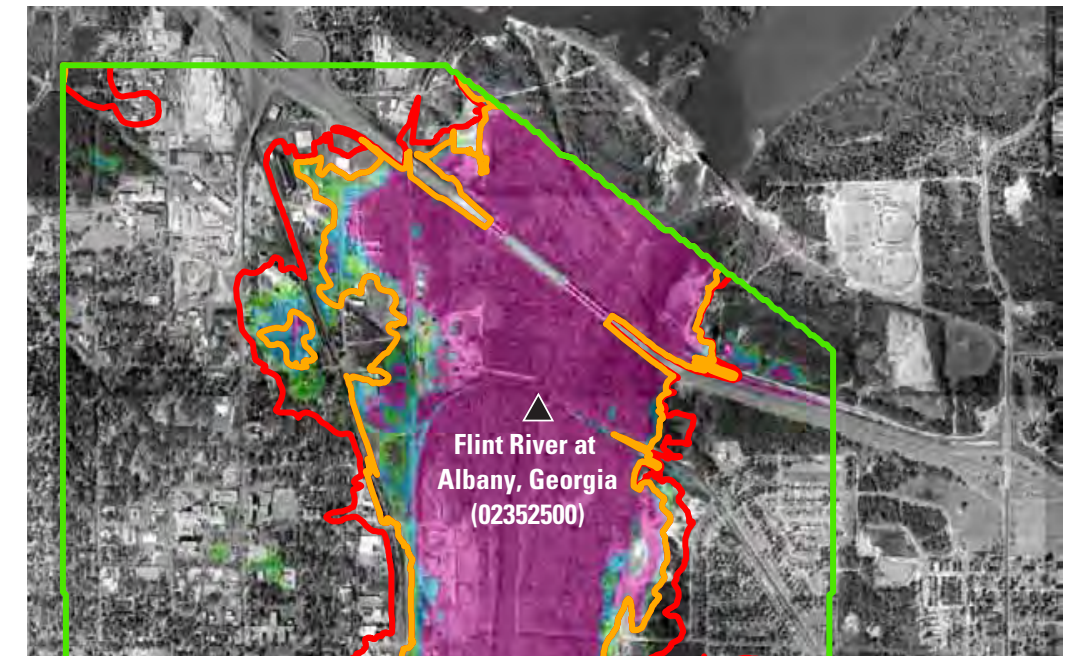

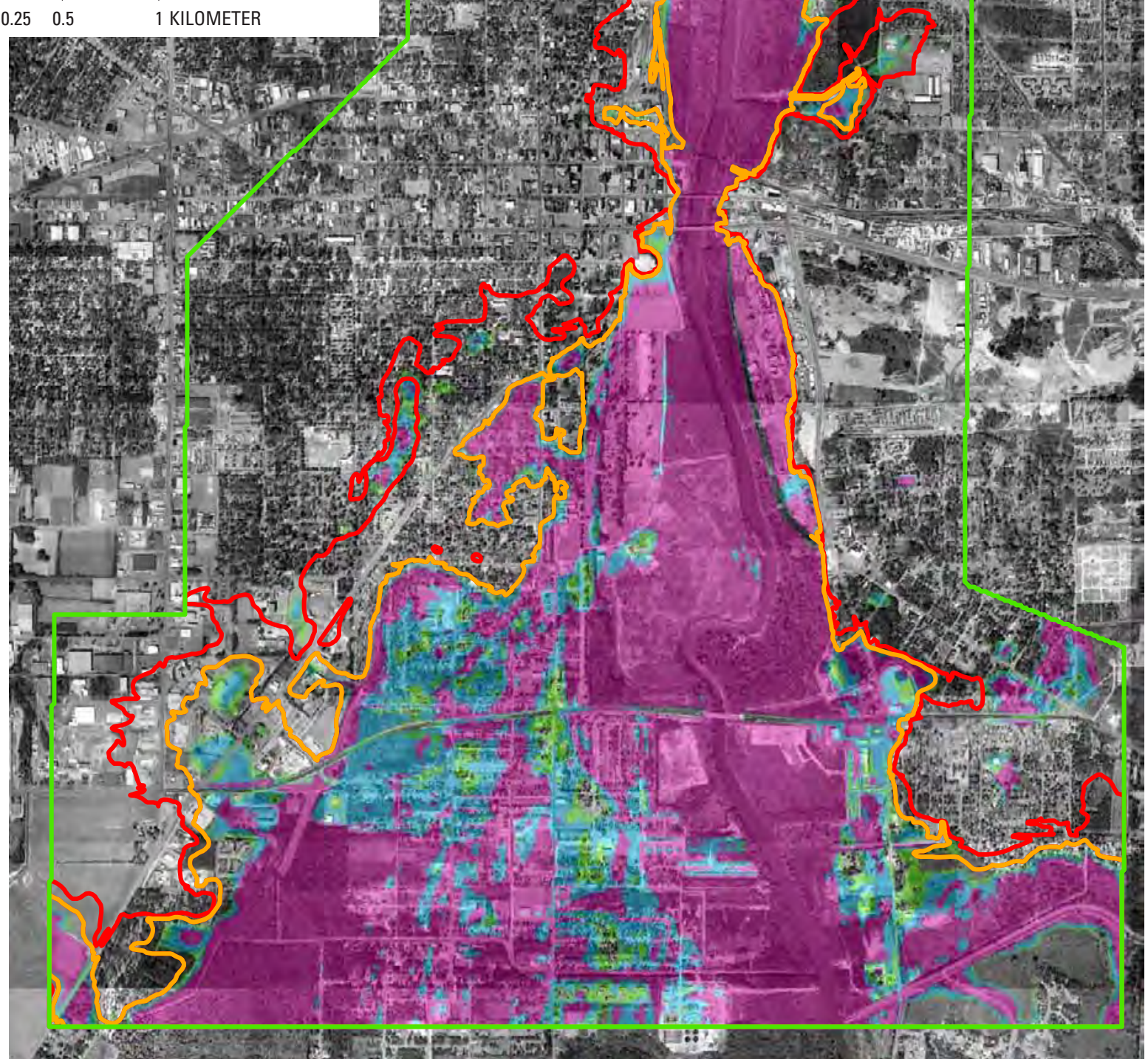

Image from Albany-Dougherty Planning Commission, 1996

Figure A25. Simulated flood-inundation hazard scale for a water-surface altitude of 189.5 feet at the Albany streamgage compared with Federal Emergency Management Agency's Digital Flood Insurance Rate Maps (DFIRM) for the Flint River in Albany, Georgia, 1998. 


\section{EXPLANATION}

WATER DEPTH ABOVE LAND SURFACE

Less than 1 foot

1 foot to 3 feet

Greater than 3 feet

DFIRM 500-year floodplain

DFIRM 100-year floodplain

Study area

$\Delta$ USGS streamgage

Flood altitude at gage: 190.5 feet NAVD 88 Gage stage: 41 feet

Inflow: 110,000 cubic feet per second

$0.25 \quad 0.5$

1 MILE

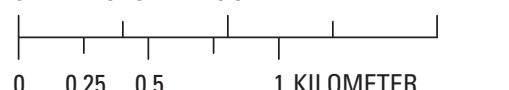

\section{$\begin{array}{lll}0.25 & 0.5 & 1\end{array}$}

N

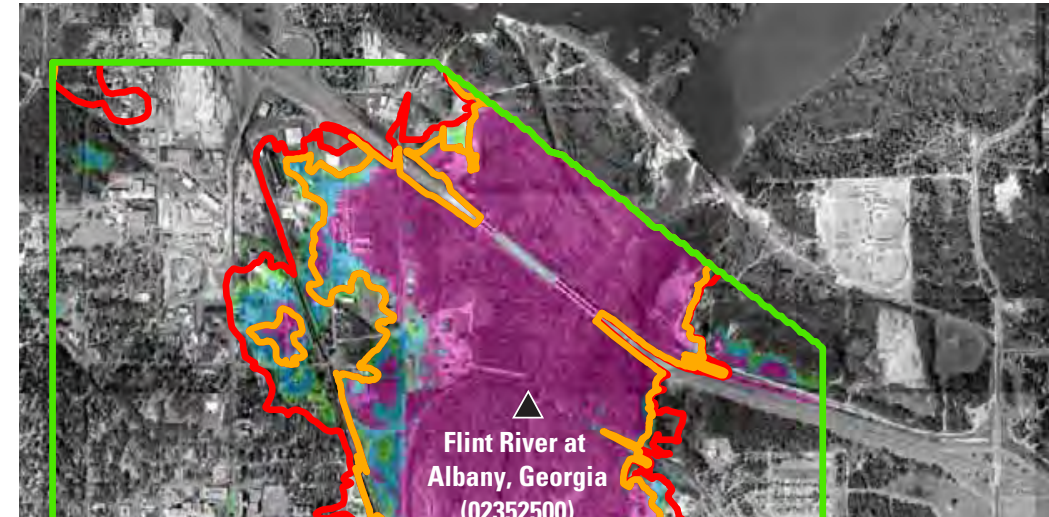

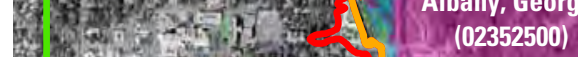

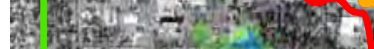

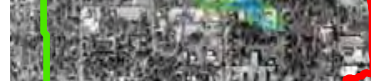

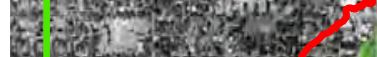

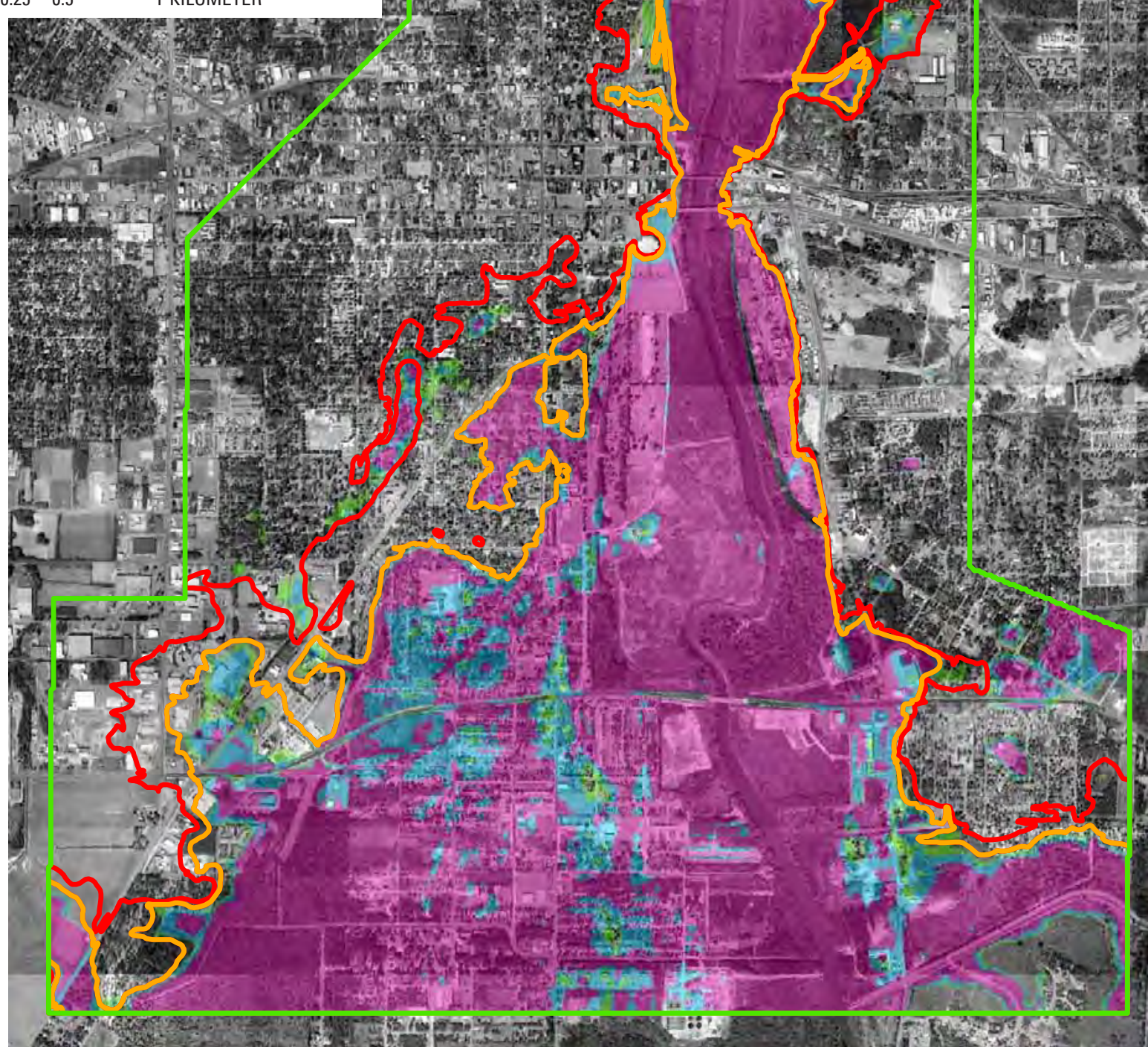

Image from Albany-Dougherty Planning Commission, 1996

Figure A26. Simulated flood-inundation hazard scale for a water-surface altitude of 190.5 feet at the Albany streamgage compared with Federal Emergency Management Agency's Digital Flood Insurance Rate Maps (DFIRM) for the Flint River in Albany, Georgia, 1998. 


\section{EXPLANATION}

\section{WATER DEPTH ABOVE LAND SURFACE}

\author{
Less than 1 foot
}

1 foot to 3 feet

Greater than 3 feet

DFIRM 500-year floodplain

DFIRM 100-year floodplain

Study area

- USGS streamgage

Flood altitude at gage: 191.5 feet NAVD 88 Gage stage: 42 feet

Inflow: 116,000 cubic feet per second

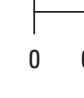

0.25

1 MILE

\begin{tabular}{ll|l|l|l|}
\hline & & & \\
0.25 & 0.5 & & 1 KILOMETER
\end{tabular}

$i$

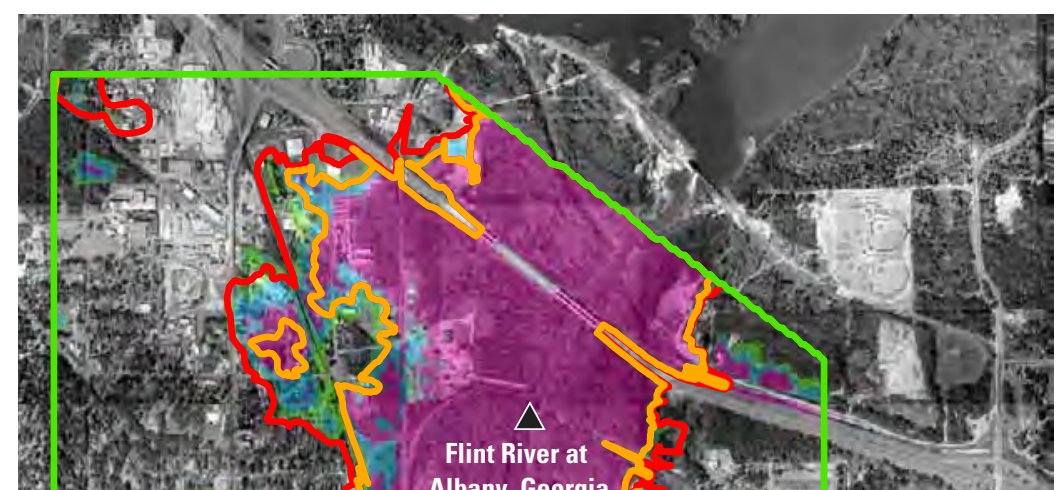

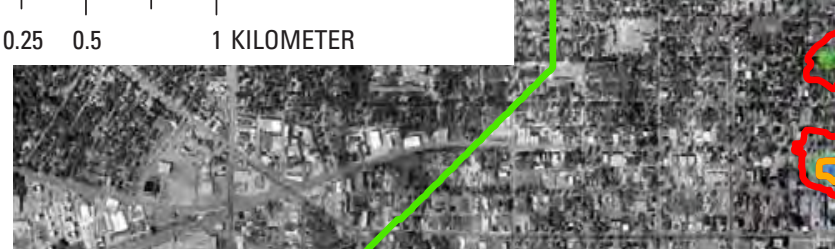
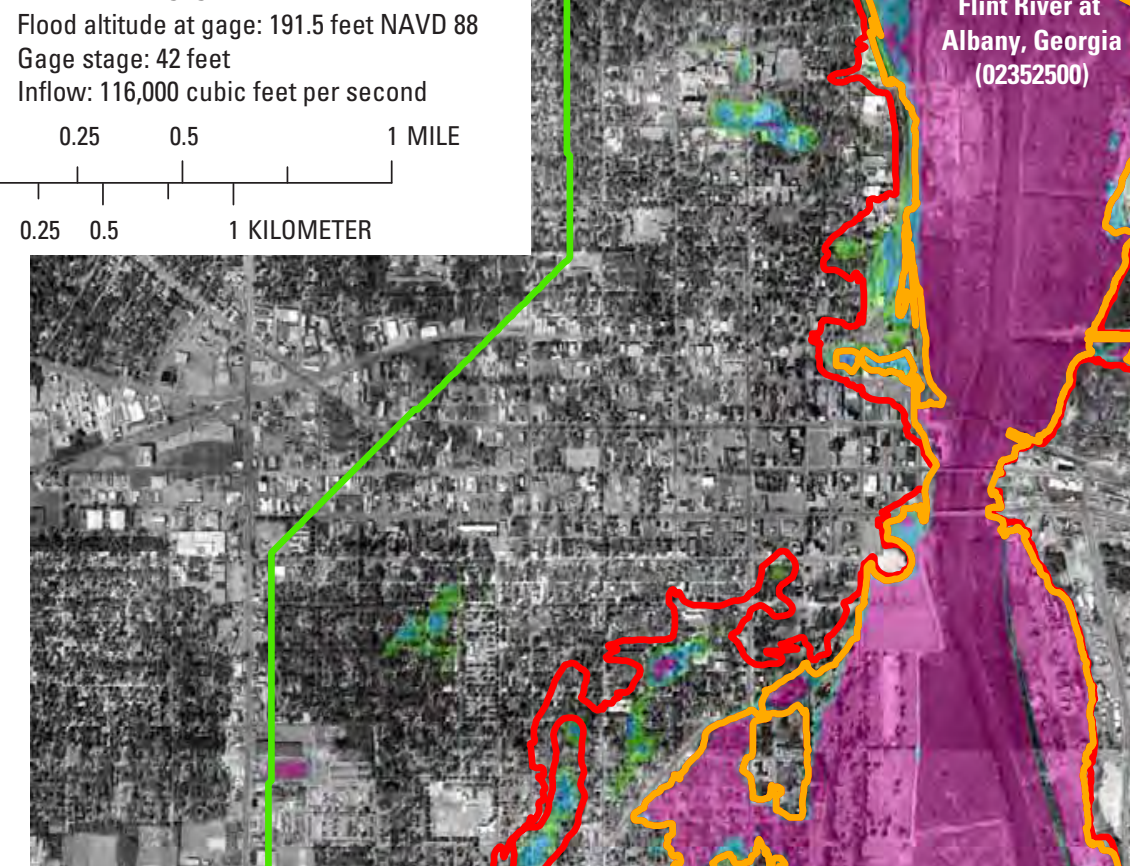
EXPLANATION

\section{WATER DEPTH ABOVE LAND SURFACE}

Less than 1 foot

1 foot to 3 feet

Greater than 3 feet

DFIRM 500-year floodplain

DFIRM 100-year floodplain

Study area

$\Delta$ USGS streamgage

Flood altitude at gage: 192.5 feet NAVD 88 Gage stage: 43 feet

Inflow: 123,000 cubic feet per second

$0.25 \quad 0.5$

1 MILE
N

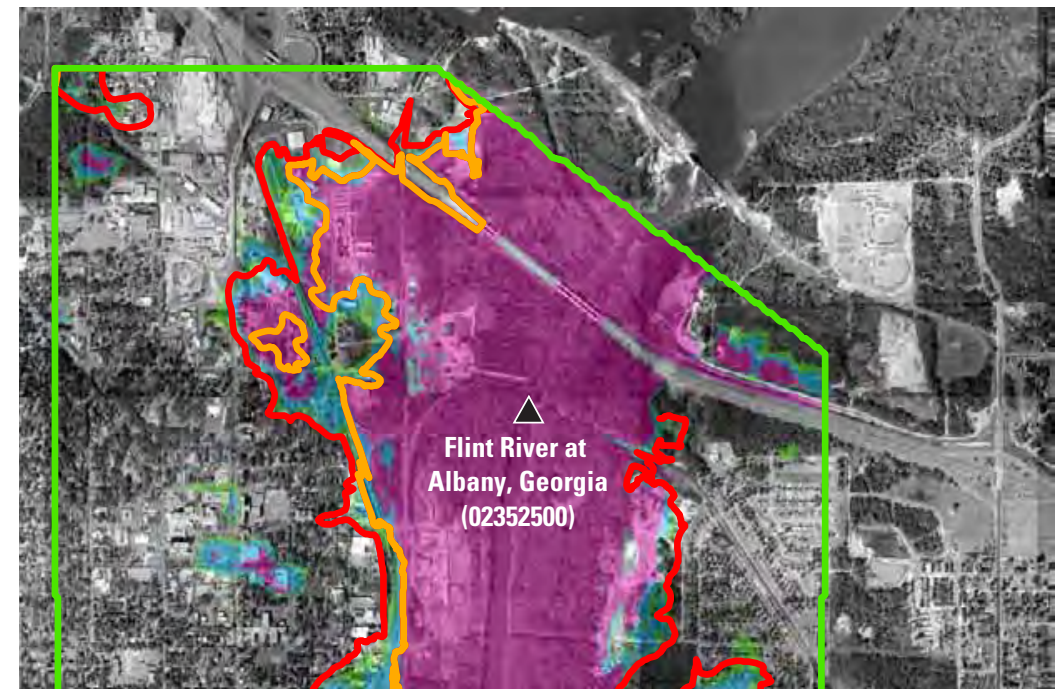

$\begin{array}{llll}0 & 0.25 & 0.5 & 1 \text { KILOMETER }\end{array}$

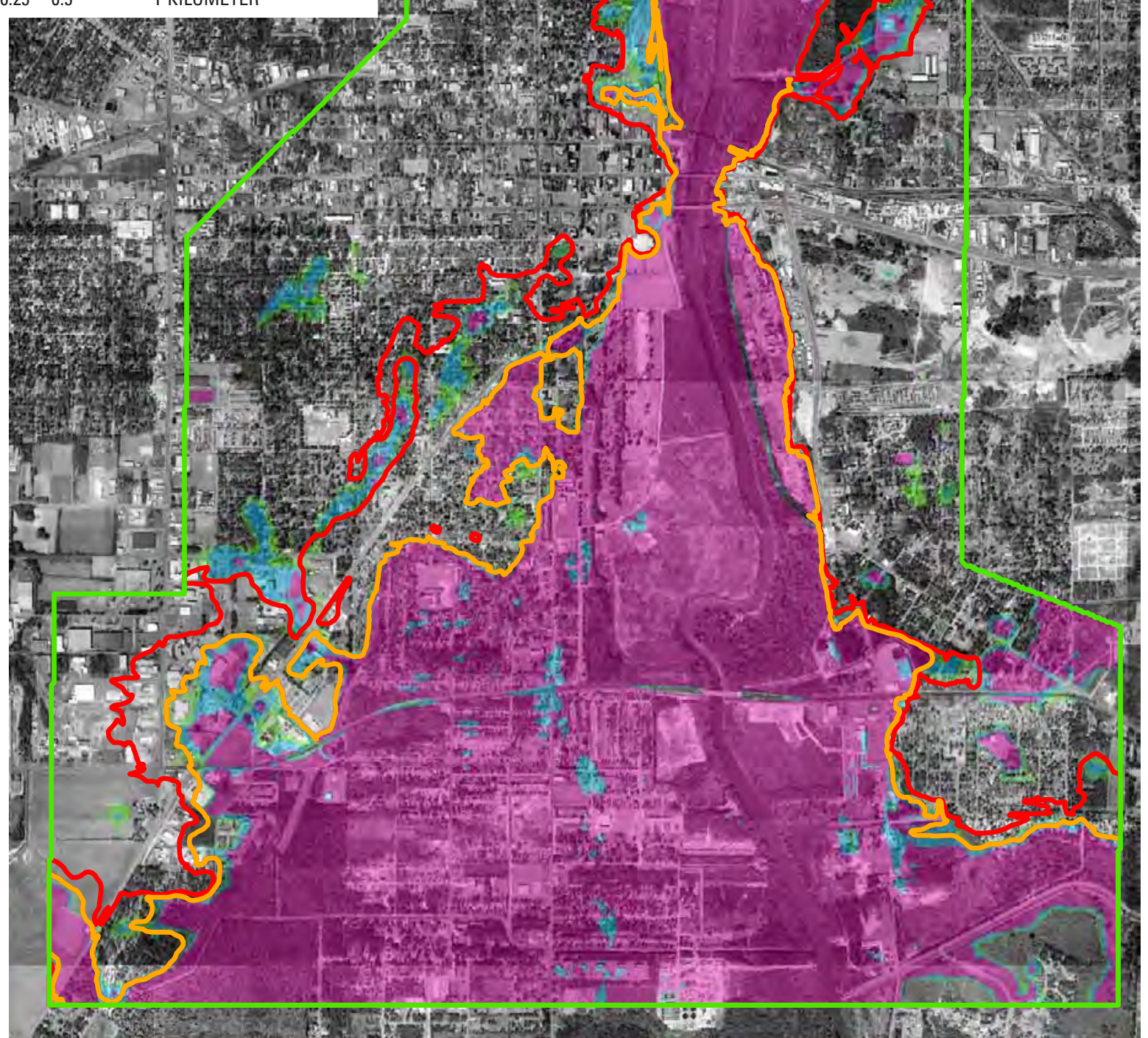

Image from Albany-Dougherty Planning Commission, 1996

Figure A28. Simulated flood-inundation hazard scale for a water-surface altitude of 192.5 feet at the Albany streamgage compared with Federal Emergency Management Agency's Digital Flood Insurance Rate Maps (DFIRM) for the Flint River in Albany, Georgia, 1998. 


\section{Appendix B. Flood extent photographs for the Flint River in Albany, Georgia}




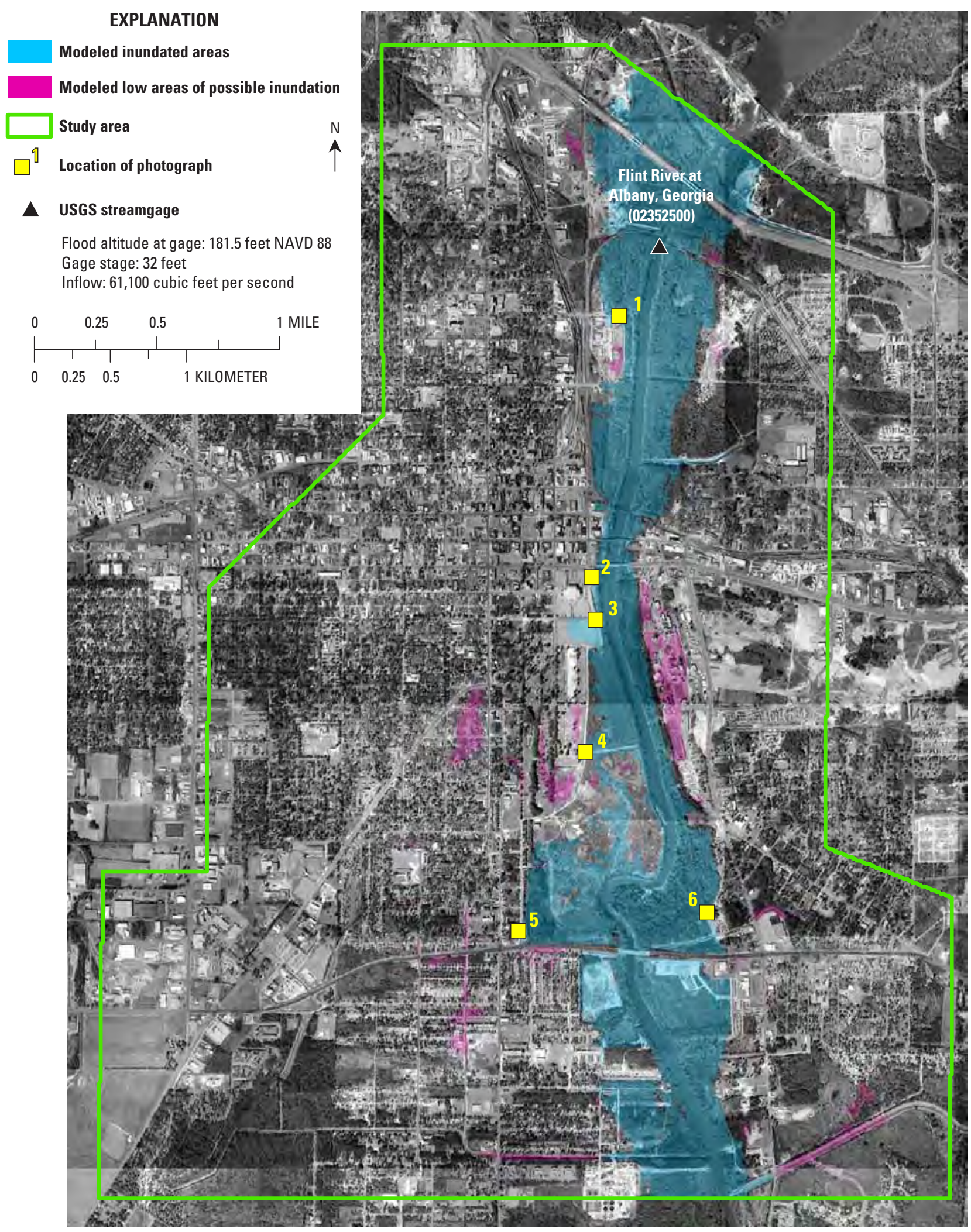

Image from Albany-Dougherty Planning Commission, 1996

Figure B1. Simulated flood inundation for a water-surface altitude of 181.5 feet at the Albany streamgage with locations of flood extent photographs (shown in Figure B2) for the Flint River in Albany, Georgia. 

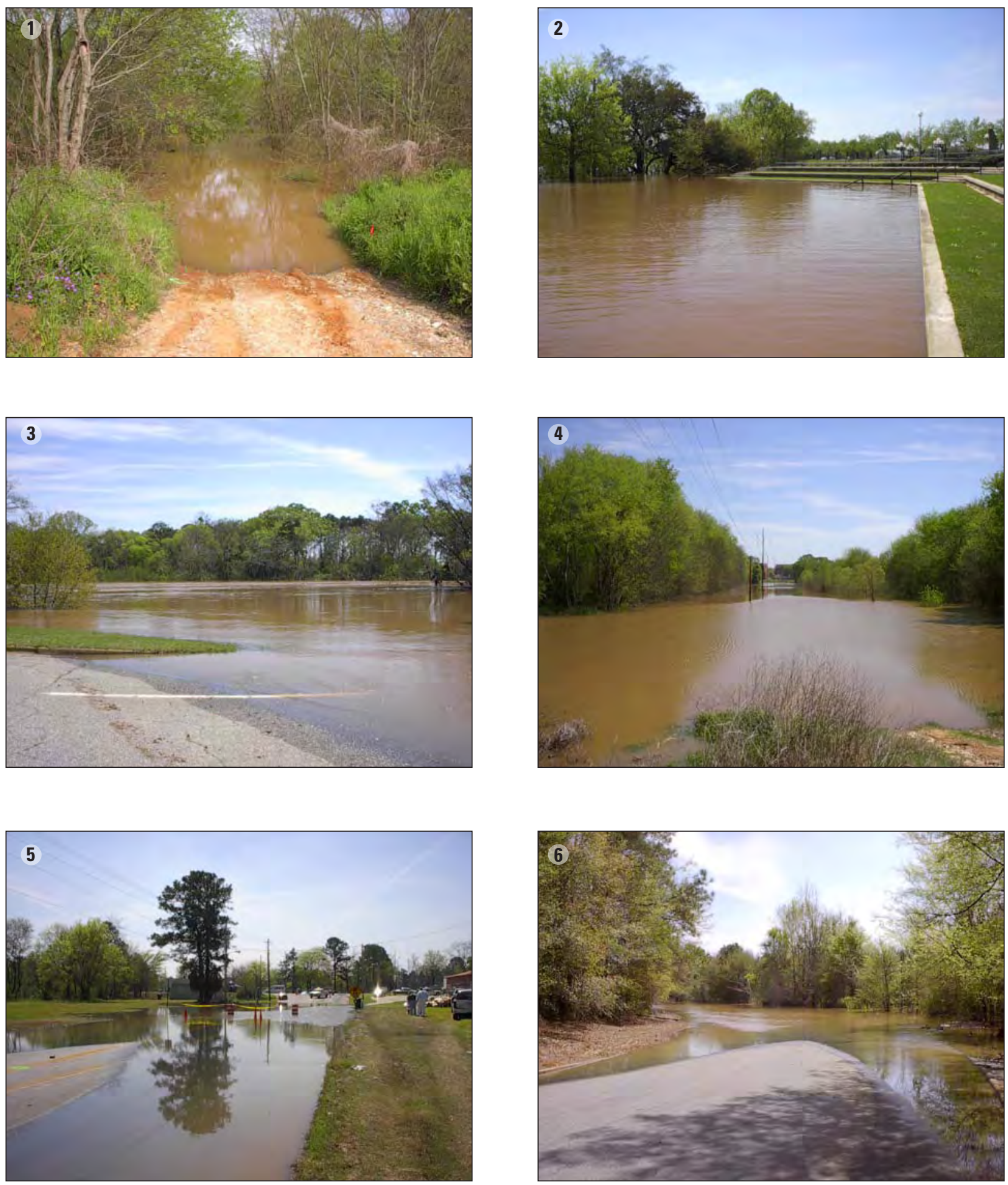

Figure B2. Flood extent photographs for the Flint River in Albany, Georgia. (Photographs by Jonathan W. Musser, USGS, March 3, 2005. See figure B1 for location.) 
Manuscript approved for publication, May 30, 2007

Prepared by USGS Georgia Water Science Center

Editing and layout by Patricia L. Nobles

Graphics by Bonnie J. Turcott

For more information concerning the research in this report, contact

USGS Georgia Water Science Center, Atlanta

telephone: 770-903-9100 